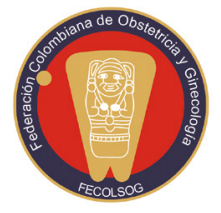

Revista Colombiana de Obstetricia y Ginecología Vol. 69 No. 4 • Octubre-Diciembre 2018 • (270-302)

ATOSIBAN EFFICACY AND SAFETY IN PREGNANT WOMEN WITH THREATENED PRETERM DELIVERY: SYSTEMATIC REVIEW OF THE LITERATURE WITH NETWORK META-ANALYSIS

\title{
Eficacia y seguridad de Atosiban en mujeres gestantes con diagnóstico de amenaza de parto pretérmino: revisión sistemática de la literatura con metaanálisis en red.
}

Lina Salazar-Castelblanco, $M D^{1}$; Paula Restrepo-Jiménez, $M D^{2}$; Pieralessandro Lasalvia, $M D^{1}$; Fabián Hernández-Tarapués ${ }^{1}$; Camilo Castañeda-Cardona, $M^{3}$; Diego Rosselli, $M^{4}$

Received: November 3/17 - Accepted: November 20/18

\section{ABSTRACT}

Objective: To assess the efficacy and safety of atosiban in pregnant women with risk of preterm delivery as compared to nifedipine, indomethacin, terbutaline, fenoterol and placebo.

Materials and methods: A systematic literature review was carried out in eight electronic databases, including Medline, Central, and Embase, using free and standardized search terms. Outcomes assessment included time delay until delivery, neonatal mortality, ratio of adverse maternal events, and ratio of neonatal complications. The quality of the evidence was evaluated per study and for the body of evidence and, whenever feasible, the information

Research Assistant, NeuroEconomix, Bogotá (Colombia).

School of Medicine, Pontificia Universidad Javeriana, Bogotá (Colombia).

3 Project Manager, NeuroEconomix, Bogotá (Colombia).

4 Department of Clinical Epidemiology and Biostatistics, School of Medicine, Pontificia Universidad Javeriana, Bogotá (Colombia).

diego.rosselli@gmail.com was synthesized into a meta-analysis. Alternatively, a narrative summary was presented.

Results: Eleven studies were included. Atosiban did not show any statistically significant differences in terms of delaying delivery versus other uterine contraction inhibitors. The neonatal mortality was lower compared to indomethacin $(\mathrm{RR}=0.21 ; 95 \%$ CI: 0.05 to 0.92 ), and the percentage of total maternal adverse events was lower compared to fenoterol $(\mathrm{RR}=0.16 ; 95 \% \mathrm{CI}: 0.08$ to 0.31$)$, nifedipine $(\mathrm{RR}=0.48 ; 95 \% \mathrm{CI}: 0.3$ to 0.78$)$, and terbutaline $(\mathrm{RR}=0.44$; 95\% CI: 0.28 to 0.71$)$.

Conclusions: Atosiban has similar efficacy for delivery delay in patients with risk of preterm delivery as compared to other agents (moderate certainty), showing some advantages regarding neonatal mortality (low certainty) versus indomethacin, and compared to fenoterol, nifedipine and terbutaline in terms of maternal adverse events (moderate certainty). 
Keywords: preterm labor, meta-analysis, nifedipine, indomethacin, terbutaline, fenoterol, placebos, and medication-associated adverse reactions.

\section{RESUMEN}

Objetivo: evaluar la eficacia y seguridad de atosiban en gestantes con amenaza de parto pretérmino comparado con nifedipino, indometacina, terbutalina, fenoterol y placebo.

Materiales y métodos: se realizó una revisión sistemática de la literatura en ocho bases de datos electrónicas (Medline, Central, Embase, entre otras), mediante términos de búsqueda libres y estandarizados. Los desenlaces evaluados incluyeron tiempo de retardo del parto, mortalidad neonatal, proporción de eventos adversos maternos y proporción de complicaciones neonatales. Se evaluó la calidad de la evidencia por estudio y para el cuerpo de evidencia, y se sintetizó la información mediante metaanálisis, cuando fue posible; de lo contrario, se resumió de forma narrativa.

Resultados: se incluyeron once estudios. Atosiban no mostró diferencias estadísticamente significativas en retardo del parto contra otros uteroinhibidores. Mostró menor mortalidad neonatal que la indometacina ( $R R=0,21$; IC $95 \%$ : 0,05 a 0,92), y menor proporción de eventos adversos maternos totales que el fenoterol (RR = 0,16; IC 95\%: 0,08 a 0,31), el nifedipino ( $R R=0,48$; IC 95\%: 0,3 a 0,78) y la terbutalina $(\mathrm{RR}=0,44$; IC $95 \%$ : 0,28 a 0,71). Conclusiones: atosiban tiene una eficacia similar para retardar el parto ante la amenaza de un parto pretérmino con otros comparadores (certeza moderada), con ventajas frente a indometacina en mortalidad neonatal (certeza baja) y frente a fenoterol, nifedipino y terbutalina en eventos adversos maternos (certeza moderada).

Palabras clave: trabajo de parto prematuro, metaanálisis, nifedipino, indometacina, terbutalina, fenoterol, placebos, reacciones adversas relacionadas con medicamentos.

\section{INTRODUCTION}

The risk of preterm delivery is defined as onset of labor generating changes in the cervix to allow for the descent and birth of the baby before week 38 (1). Preterm delivery, defined as childbirth between 20 and 37 weeks plus 6 days of pregnancy, is the major cause of neonatal morbidity and mortality (2). It is estimated that every year there are approximately 15 million preterm deliveries worldwide, which corresponds to $11.1 \%$ of all births (3). A study led by the World Health Organization (WHO) found that the percentage of preterm deliveries in South America/ Latin America is 8.1 and $7.9 \%$, respectively, versus the total number of deliveries recorded in each region (4). In Colombia, according to the figures of the National Statistics Department (Departamento Administrativo Nacional de Estadística - DANE), premature deliveries accounted for $20.1 \%$ of all births in 2016 (5).

Risk factors associated with preterm delivery include maternal risks such as age (under 18 or over 40 years), low socioeconomic bracket, smoking, use of psychoactive substances or alcohol, excess physical activity, stress and malnutrition, uterine disorders, infections, a history of preterm delivery, rupture of membranes, multiple gestation, first and second trimester bleeds, and fetal causes, such abnormal placentation $(1,6)$.

It has been estimated that $28 \%$ of the fetal deaths that occur annually are due to preterm deliveries (7). Neonatal morbidity and mortality are inversely proportional to gestational age at birth: $99 \%$ of preterm delivery-associated morbidity and mortality occur before 34 weeks (2). Of babies born at 24 weeks, $80 \%$ will die, whilst $90 \%$ of the babies born during week 30 of gestation will survive. It has been shown that babies born at 22, 24 and 26 weeks of gestation show mortality rates of 54, 21 and $2 \%$ respectively, with higher disease-free oneyear survival rates greater than $0.02,14.1$ and $45.9 \%$ (8). This means that prolonging pregnancy increases the probability of survival for the newborn. 
Premature neonates have higher rates of neurodevelopmental disorders (5), respiratory complications such as asthma and bronchitis (9), and potential physical, psychological and economic consequences (10). Long term impact on premature birth survivors include: visual impairment (blindness, myopia, retinopathy, hyperopia) in 25\% of cases, hearing impairment in 5-10\%, prematurity-related chronic pulmonary disease requiring oxygen supplementation at home (40\%), cardiovascular disease including high blood pressure, reduced pulmonary function, higher asthma rates, growth failure and accelerated weight gain during adolescence. Neurodevelopmental problems include gait disorders, overall developmental delay, and psychiatric and behavioral sequelae (attention deficit/hyperactivity disorder, increased anxiety and depression disorder) (10).

The diagnosis of preterm labor is based on the presence of regular uterine contractions causing cervical changes (11). According to the Bogotá Health Secretariat clinical care guidelines, diagnosis is made in patients between 20 and 37 weeks of pregnancy, showing uterine activity of at least 4 contractions in 20 minutes, or 8 contractions in one hour, with intact membranes and cervical changes of $80 \%$ effacement and $2 \mathrm{~cm}$ dilation (1).

Preterm delivery treatment is indicated in patients between 20 and 37 weeks, with regular uterine activity. Tocolytic treatment is contraindicated in patients rupture of membranes, chorioamnionitis, congenital malformations and fetal demise (1). Treatment for preterm labor emphasizes hydration, since hypovolemia may be associated with increased uterine activity. However, tocolytic agents are used to inhibit uterine contractions with the purpose of delaying labor and achieving an effective maturation of the fetus $(1,2,12)$. There are different drug families that may be used as tocolytic agents, including $\beta_{2}$-agonists, calcium channel blockers, oxytocin receptor antagonists, and cyclooxygenase inhibitors (13). The choice of a tocolytic agent is based on the patient's particular characteristics, and the drug's safety profile and effectiveness (14).
Atosiban is an oxytocin receptor antagonist, a tocolytic agent approved in 2007 by the National Food and Drug Surveillance Institute (Instituto Nacional de Vigilancia de Medicamentos y Alimentos - INVIMA) to delay imminent preterm delivery in pregnant women over the age of 18, with 24 to 33 complete weeks of pregnancy and normal fetal heart rate, presenting with threatened preterm delivery. INVIMA is the regulatory agency that issues approval for marketing medications in Colombia.

A review of meta-analyses found in the literature showed that none of the studies identified through database search assessed all outcomes or conditions of interest for our study, namely, maternal gestational age at the time of delivery, percentage of neonatal mortality, newborn respiratory distress syndrome, intraventricular bleeding, periventricular leukomalacia, necrotizing enterocolitis, percentage of maternal adverse events, and neonatal complications. Given the recognition that preterm delivery management is of paramount importance for reducing maternal and neonatal complications, this study focuses on evaluating the effectiveness and safety of atosiban versus nifedipine, indomethacin, terbutaline, fenoterol and placebo for the prevention of preterm delivery, taking perinatal and maternal outcomes into account.

\section{MATERIALS AND METHODS}

The final research question of this paper is shown in Table 1. This question was fine-tuned through expert consultation to define the need to limit the gestational age to that indicated by the National Food and Drug Surveillance Institute (INVIMA) (between 24 and 33 full weeks) and not consider magnesium sulphate as a comparator, as was initially suggested.

The inclusion criteria were the following:

Types of studies: Randomized clinical phase III trials with no publication date restriction, available in full text for comprehensive assessment when included in the review and meta-analysis.

Type of population: Studies that included adult pregnant patients with risk of imminent preterm 


\begin{tabular}{l|l|}
\multicolumn{1}{c}{ Table 1.} \\
\hline P & Adult patients with risk of preterm labor between 24 and 33 weeks \\
\hline I & Atosiban \\
\hline C & Nifedipine, indometacine, terbutaline, fenoterol, placebo. \\
& $\begin{array}{l}\text { Effectiveness } \\
\text { Primary } \\
\text { Delivery delayed for more than } 48 \text { hours } \\
\text { Delivery delayed for more than } 7 \text { days } \\
\text { Secondary } \\
\text { Gestational age at the time of birth } \\
\text { O Safety } \\
\text { Primary } \\
\text { Neonatal mortality rate } \\
\text { Maternal adverse event rate } \\
\text { Secondary } \\
\text { Neonatal Respiratory Distress Syndrome } \\
\text { Intraventricular Hemorrhage } \\
\text { Periventricular Leukomalacia } \\
\text { Rate of neonatal complications }\end{array}$ \\
\hline According to reports in the trials \\
\hline
\end{tabular}

delivery, defined as regular uterine contractions at least 30 seconds in duration and a frequency of more than 4 contractions every 30 minutes; cervical dilation of 1 to $3 \mathrm{~cm}$ ( 0 to $3 \mathrm{~cm}$ for nulliparous women) and effacement $>50 \%$; gestational age 24 to 33 full weeks and with normal fetal heart rate (110-160 bpm) according to the expert panel and the Colombian guidelines for the management of preterm delivery (1).

Type of intervention: The technology of interest was atosiban and the comparators were nifedipine, indomethacin, terbutaline, fenoterol, and placebo.

The primary effectiveness outcomes were absence of delivery at 48 hours and at 7 days, and secondary outcomes were the difference in gestational age at the time of delivery. Concerning safety, the primary outcomes were percentage of neonatal mortality and the proportion of maternal adverse events; the secondary outcomes were newborn respiratory distress syndrome, the frequency of intraventricular hemorrhage, the frequency of periventricular leukomalacia, and the percentage of total neonatal complications.

Any trials that were not available in full text but only as posters or abstracts were excluded because the complete information on the characteristics and outcomes of those references were not available for inclusion in the analysis.

\section{Search Strategy}

A literature search was conducted using the following databases: Medline via PubMed, EMBASE (Elsevier), Cochrane Database of Systematic Reviews (Wiley platform), Database of Abstracts of Reviews of Effects (DARE) (Wiley platform), Cochrane Central Register of Controlled Trials (CENTRAL) (Ovid platform), Lilacs (Virtual Heal Library VHL, iAHx interface), WHO International Clinical Trials Registry Platform ICTRP portal, and ClinicalTrials.gov (Annex 1). 
The key words used for the search were defined based on the PICOT question (Table 1). The first step was the inclusion of the terms to define the population and then the search terms for the technologies involved.

The criteria for defining the population as free text and controlled vocabulary (MeSH, Emtree and DeCS) were: "Obstetric labor," "Premature" [Mesh] and "Preterm birth". The terms for the health technologies of interest that were associated with the Boolean operator odds ratio (OR) were: "Nifedipine," "Terbutaline," "Atosiban," "Indomethacin," "Fenoterol" and "placebo". Finally, the set of search terms that defined the population was combined with the terms of the health technologies of interest using the Boolean operator "AND".

The search terms used were adjusted according to the search platform of each electronic database. No filters were used for text availability (abstract), date of publication, type of study, or language (Annex 1).

Likewise, a manual "snowball" search was conducted based on the list of references of each article selected by the reviewers in search for other publications that met the previously defined search criteria.

\section{Screening of references and selection of studies:}

Prior to the start of the process, the selection criteria of the articles were shared and questions about the selection process were answered. The screening of references was conducted independently by two investigators (LS and PR), without knowing the results of the other. Afterwards, the articles selected by each reviewer were compared, any doubts regarding the selection of the articles were resolved by consensus between the reviewers, evaluating the new title and abstract, and in case additional information was required, the full text was obtained to finally make a decision of whether to include the articles or not. In case of disagreement, a third investigator was asked to participate (DR).

\section{Assessment of the quality of the evidence}

The assessment of the quality of the evidence and the risk of bias was evaluated for each article in a paired manner by both investigators (LS and PR). The articles selected were evaluated using the tool designed by the Cochrane Collaboration for identifying any risk of bias (15). This tool assesses the risk of the following biases: selection (random generation and blind assignment were taken into account); execution (blinding of the participants and the staff was evaluated); detection (outcome assessment risk was evaluated); attrition (the presence of incomplete data was assessed); and reporting (assessment for selective data reporting was performed). Based on these considerations, each article was categorized accordingly as: high, low or undetermined risk of bias. Disagreements were solved by a third researcher (DR).

Additionally, the tool developed by the Grading of Recommendations Assessment, Development and Evaluation (GRADE) working group was used to assess the quality of the evidence set found for each outcome (16). This tool assesses the number of studies available for each outcome, study design, risk of bias, inconsistency in the results, the indirect nature of the results, inaccuracy, and other considerations (dose-response gradient and publication bias). Considerations for network meta-analysis assessment were taken into account (17). Summary tables for quality assessment were reported in accordance with the proposed network meta-analysis model (17).

\section{Data extraction and evidence synthesis}

For data extraction, the selected publications as well as the reports published as annexes and supplements were taken into consideration whenever it was necessary and depending on their availability. Extracted data included interventions, primary study inclusion and exclusion criteria, number of patients, age, clinical characteristics, type of analysis, outcomes assessed, ethical approval, site, and funding. Data for all the studies were uploaded to an 
Excel ${ }^{\circledR}$ worksheet. Data extraction was conducted by searching for the information reported as part of the intention-to-treat analysis. When available, information derived from safety analysis was considered, specifically in relation to adverse events. The total number of patients in each arm and the number of patients analyzed were considered for data extraction for the arms in each of the studies. Following data extraction, quality control of the information obtained was performed by means of comparison with the records of the primary studies. For adverse event analysis, all reported maternal events for each of the studies, both in the intervention group as well as in the control group, were added and compared.

Statistical analysis. After collecting the studies, assessments to determine head-to-head comparisons were performed. In those cases in which direct information was not derived from a comparison, the possibility of indirect comparisons using network meta-analyses was evaluated. To this end, the first thing that was determined was whether there was a comparison network that could enable an indirect comparison. When that was the case, the characteristics of the populations and the methods of each study were verified in order to assess transitivity within the information set found. In those cases in which this was not possible, a narrative report of the outcomes was made based on the data reported in the primary studies. If not, a network meta-analysis was conducted using the $\mathrm{R}$ statistical tool ( $\mathrm{R}$ Development Core Team), version 3.2.3 and the $R$ package netmeta, version 0.9-2, which uses a frequency analytical method. For categorical outcomes in each study, event and population numbers, or the comparison measurement, were extracted: risk ratio (RR), hazard ratio (HR), odds ratio (OR), with their respective scatter or confidence interval measurement for assessment (15). For continuous outcomes, the mean for each group was extracted together with scatter or mean difference and confidence interval. A priori subgroup analyses were not considered.

This information was entered into the statistical software package using Microsoft Excel templates. Once the analysis was completed, the presence of $\mathrm{I}^{2}$ statistical heterogeneity was verified, categorizing it as suggested in the Cochrane manual (18): not significant between 0 and 40\%, moderate between 30 and $60 \%$, substantial between 50 and $90 \%$, and considerable between 75 and 100\%. Additionally, the intra- and inter design Q test was performed in order to assess heterogeneity and consistency. Model consistency was verified by means of a comparison between direct available relationships and model estimates. The model contains estimates for all possible comparisons between all outcomes. Results were reported in league tables, showing the appropriate model estimates and direct results according to the outcome. Using a frequentist methodology similar to the Surface Undercumulative Ranking Curve (SUCRA), employed in Bayesian models and available in the netmeta package, the probability of being the best option among the ones used in the model was calculated.

Ethical considerations. Given that this research consists of a review of the literature and a meta-analysis, it is considered risk-free. Pursuant to Article 11 of Resolution 8430 of 1993 (19), risk-free research is described as consisting of "studies that use retrospective document review techniques and methods, and studies where no intervention or intentional modification to the biological, physiological or social variables of the subjects is performed. These include clinical record reviews, interviews, questionnaires and other studies which do not identify or deal with sensitive subject behavior considerations".

\section{RESULTS}

Overall, 5245 references were found as a result of the screening. After removing duplicates, a total of 4599 references were obtained. Of these, 30 which 
met the inclusion criteria by title and abstract were included for full-text evaluation. Finally, 11 studies (20-30) corresponding to randomized clinical trials were selected for inclusion in the qualitative and quantitative analyses. The characteristics of the studies included are described in Annex 2; most were only two-arm studies. All the studies met the gestational age for inclusion in one of the following ways: consideration of the entire range of interest, partial consideration of the range of interest, consideration of a wider range, but reporting the information for the range of interest. The majority of the studies included a population of young women with a mean age ranging between 25 and 30 years. Singleton and twin pregnancies were considered in the majority of the studies. The reasons for reference exclusions are shown in Annex 3. Four records with no results were found in clinicaltrials.gov and 1 reference was a poster report and, for this reason, they were not considered in the results. For another study, there was a record stating that it had been withdrawn before the initiation of the trial. Of the remaining 9 studies, 9 did not represent the inclusion criteria for the populations (reports of gestational ages outside the range considered, excess cervical dilation), and two showed aggregate results for various comparators (beta-agonists together, medications and bedrest grouped together). Figure 1 shows the PRISMA reference screening flow diagram.

\section{Risk of biases}

The 11 phase III controlled clinical trials were assessed. (20-30) High risk of performance and detection biases was identified for 5 open-label studies $(20,21,23,24,28)$. For the remaining studies, low or indeterminate risk of selection, performance, detection, attrition reporting and other forms of biases were found. Risk-of-bias summary tables are shown in Figure 2.

\section{Quality of the evidence}

Annex 4 shows GRADE evidence profiles for important outcomes with evidence summary tables, together with the network geometry.

\section{Effectiveness}

Delivery delay of more than 48 hours. 8 relevant studies were identified for this outcome, (20, 21, 23-26, 28, 30 ) for a total of 1436 randomized patients; a network meta-analysis was performed. The results are summarized in Table 2. No statistically significant differences are found between atosiban and fenoterol ( $R R=1.26$; 95\% CI: 1-1.59, moderate certainty), nifedipine ( $\mathrm{RR}=1.02$; 95\% CI: 0.91-1.15, moderate certainty) and terbutaline $(\mathrm{RR}=1.06 ; 95 \%$ CI: 0.93-1.21, moderate certainty). Similar results are observed in head-to-head comparisons. No significant differences are found either between fenoterol, nifedipine and terbutaline (Table 2). In this analysis, $\mathrm{I}^{2}$ was $44.7 \%$ (moderate heterogeneity) with intra- and inter-design $p$ value in the $\mathrm{Q}$ test of 0.11 and 0.24 , respectively, that is, not statistically significant. No relevant inconsistencies were found for this analysis (Annex 4).

Regarding the comparison between atosiban and placebo, the head-to-head study (22) reports a composite result together with the outcome of not needing additional tocolytic agents at 48 hours. For this comparison in women between 28 and 33 full weeks of gestation, the study found an absolute risk difference of 14\% (95\% CI: 4-23).

Delivery delay of more than 7 days: 7 relevant studies were identified for this comparison (20, 21, 23-26, 29) with a total of 1305 randomized patients; a network meta-analysis was performed (Table 3). No statistically significant differences were found between atosiban and fenoterol $(\mathrm{RR}=1.18 ; 95 \%$ CI: 0.71-1.95, moderate certainty), nifedipine $(\mathrm{RR}=1.06 ; 95 \% \mathrm{CI}: 0.82-1.37$, moderate certainty) and terbutaline $(\mathrm{RR}=1.37$; 95\% CI: 0.99-1.89, low 


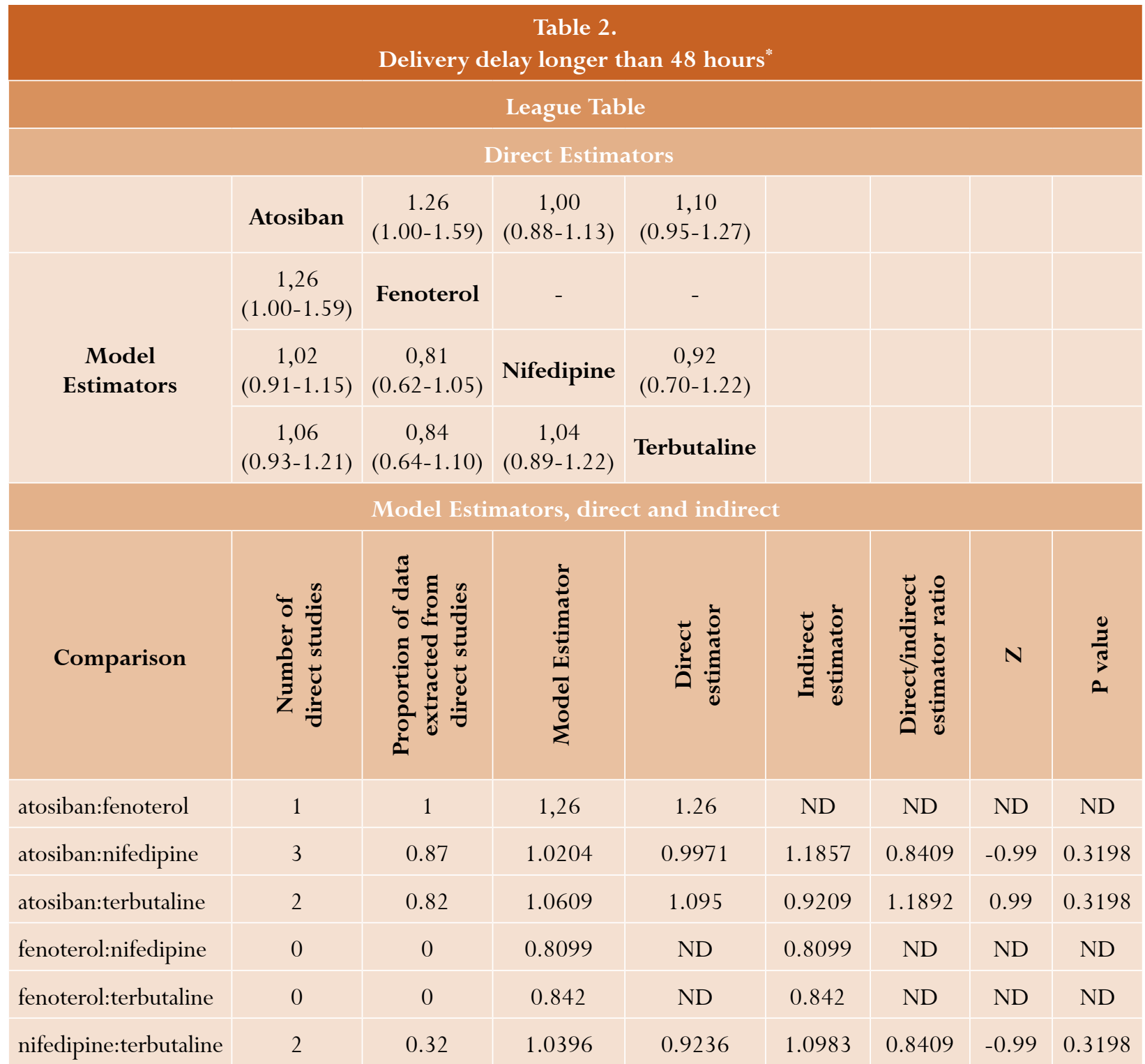

* We present the table with comparisons of each element reported in the column versus the element in every row. In the lower part are the model estimators; the direct tools are in the upper part, when available. The table including differences between direct and indirect estimators for each comparison is also reported with their respective statistical test.

certainty). Similar results are observed in head-tohead comparisons in all cases, except the comparison with terbutaline, where direct comparisons in 2 studies show a statistically significant difference. $(\mathrm{RR}=1.61 ; 95 \% \mathrm{CI}: 1.08-2.4)$ (Tabla 3$). \mathrm{I}^{2}$ for this analysis was $82 \%$ with good Q test intra- and interdesign $p$ values of 0.0003 and 0.052 , respectively. This corresponds to moderate to severe heterogeneity (Annex 4).
As for the comparison with placebo, the headto-head study (22) provides a composite result together with the outcome of not requiring additional tocolytic agents at 7 days. For this comparison, an absolute risk difference of 17\% (95\% CI: 7-26\%) was found in pregnant women between 28 and 33 full weeks of gestation.

Gestational age at the time of delivery. Four relevant studies were identified for this outcome $(23,24,27$, 
Figure 1.

PRISMA flow diagram for screening and selection of evidence (de novo search).

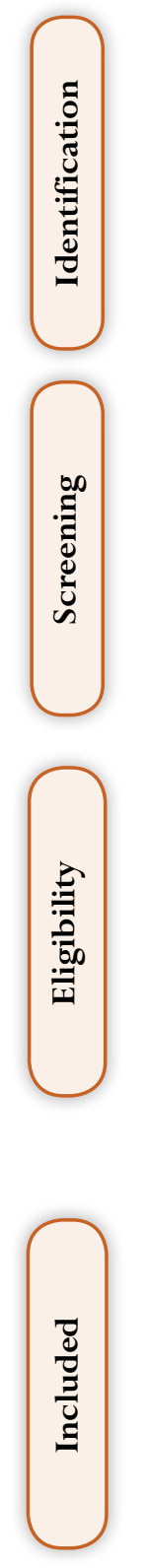

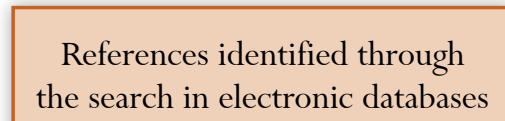

$\mathrm{n}=5.245$
References identified by means of other search methods

$$
\mathrm{n}=0
$$

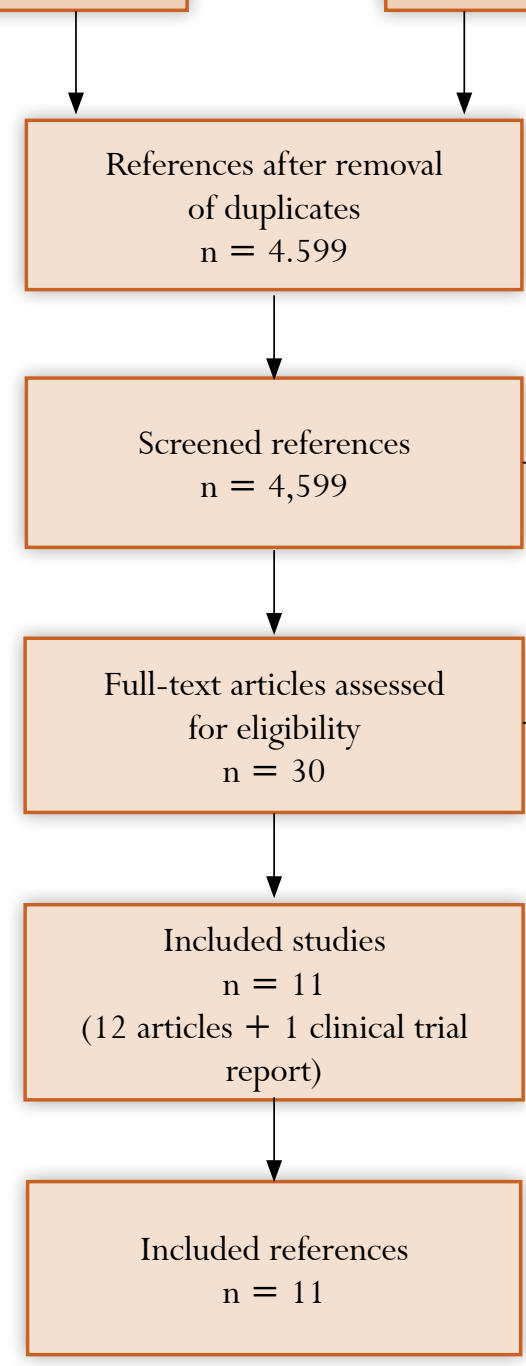

Excluded references

$$
\mathrm{n}=5
$$

Excluded full-text articles

$$
\mathrm{n}=17
$$

Reason \# 1. Abstracts, not full-text articles

Reason \# 2. 1 excluded article because of incomplete report of the results

Reason \# 3. Did not assess the population of interest
30), with a total of 849 randomized patients; a network meta-analysis was performed (Table 4). No statistically significant differences were found between atosiban and indomethacin $(0.91$; 95\% CI: -7.74$5.92)$, nifedipine $(-0,91 ; 95 \% \mathrm{CI}:-3.54-1.71)$ and terbutaline (-0.13; 95\% CI: $-5-4.74)$. In this analysis, $\mathrm{I}^{2}$ was $0 \%$, with an intra-design $p$ value of 0.85 in the
Q test, and undetermined inter-design value. There is consistency of direct and indirect comparisons in this case, given the network structure.

\section{Safety}

Neonatal mortality. Three relevant studies were identified for this outcome $(24,25,27)$. Based on the 
Figure 2.

Risk of bias of primary studies included, Cochrane tool for risk

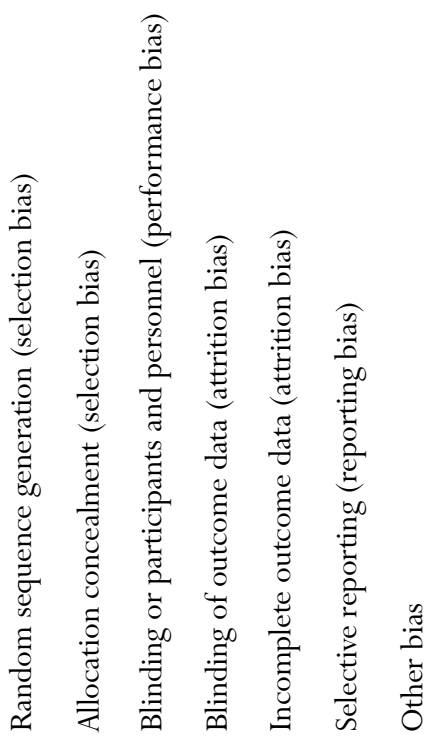

Cabar 2008, Atosiban vs Terbutalina European 2001, Atosiban vs Terbutalina Kashanian 2006, Atosiban vs Nifedipino Klauser 2012, Indometacina vs Nifedipino Mawaldi 2007, Nifedipino vs Terbutalina Nonnenmacher 2009, Atosiban vs Fenoterol Romero 2000, Atosiban vs Placebo Salim 2012, Nifedipino vs Atosiban Valdes 2012, Nifedipino vs Fenoterol Van Vliet 2016, Nifedipino vs Atosiban Weerakul 2001, Nifedipino vs Terbutalina

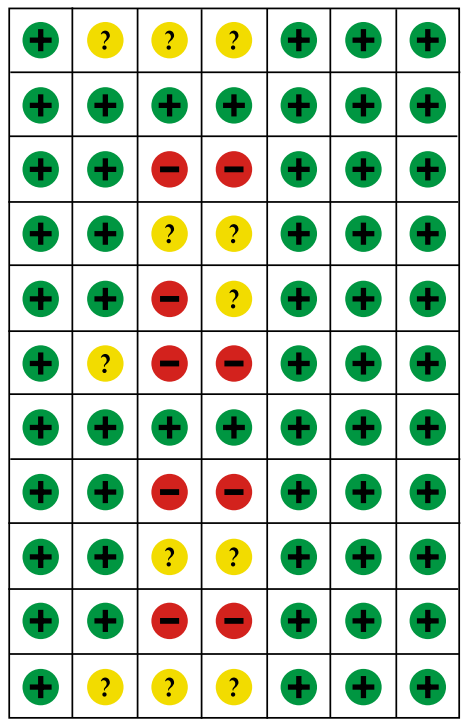

other studies with a total of 835 patients randomized, a network meta-analysis was performed (Table 5). A statistically significant difference was found between atosiban and indomethacin $(\mathrm{RR}=0.21$; 95\% CI: 0.05-0.92, low certainty), but no significant differences were found with nifedipine $(\mathrm{RR}=0.45 ; 95 \% \mathrm{CI}: 0.19-1.1$, low certainty) or terbutaline $(\mathrm{RR}=0.5 ; 95 \% \mathrm{CI}: 0.13-1.91$, low certainty). No significant differences were found between indomethacin, nifedipine and terbutaline in the meta-analysis. Similar results are observed in the head-to-head comparisons (Table 5) (24, 25, 27). No significant differences were found between fenoterol, nifedipine and terbutaline. Given the 


\begin{tabular}{|c|c|c|c|c|c|c|c|c|}
\hline \multicolumn{9}{|c|}{$\begin{array}{c}\text { Table } 3 . \\
\text { Delivery delay longer than } 7 \text { days* }\end{array}$} \\
\hline \multicolumn{9}{|c|}{ League Table } \\
\hline \multicolumn{9}{|c|}{ Direct Estimators } \\
\hline & Atosiban & $\begin{array}{c}1.18 \\
(0.71-1.95)\end{array}$ & $\begin{array}{c}0.97 \\
(0.73-1.29)\end{array}$ & $\begin{array}{c}1.61 \\
(1.08-2.40)\end{array}$ & & & & \\
\hline \multirow{3}{*}{$\begin{array}{c}\text { Model } \\
\text { Estimators }\end{array}$} & $\begin{array}{c}1.18 \\
(0.71-1.95)\end{array}$ & Fenoterol & - & - & & & & \\
\hline & $\begin{array}{c}1.06 \\
(0.82-1.37)\end{array}$ & $\begin{array}{c}0,90 \\
(0.51-1.58)\end{array}$ & Nifedipine & $\begin{array}{c}1,02 \\
(0.63-1.64)\end{array}$ & & & & \\
\hline & $\begin{array}{c}1.37 \\
(0.99-1.89)\end{array}$ & $\begin{array}{c}1.16 \\
(0.64-2.11)\end{array}$ & $\begin{array}{c}1.29 \\
(0.92-1.82)\end{array}$ & Terbutaline & & & & \\
\hline \multicolumn{9}{|c|}{ Model estimators, direct and indirect } \\
\hline Comparison & 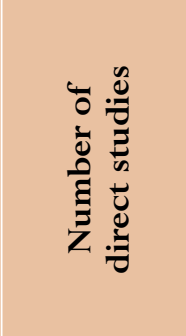 & 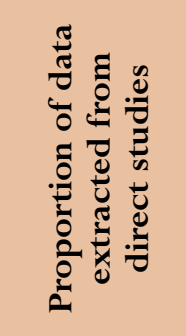 & 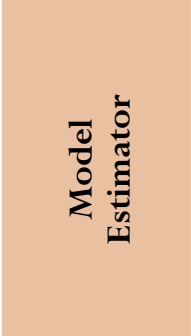 & تֶّ & 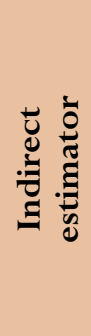 & 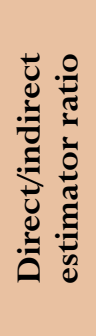 & $\mathbf{N}$ & $\underset{\substack{\frac{1}{3} \\
\frac{2}{2}}}{2}$ \\
\hline atosiban:fenoterol & 1 & 1 & 1.18 & 1.18 & ND & ND & ND & ND \\
\hline atosiban:nifedipine & 3 & 0.83 & 1.06 & 0.97 & 1.58 & 0.62 & -1.39 & 0.1632 \\
\hline atosiban:terbutaline & 2 & 0.66 & 1.37 & 1.61 & 0.99 & 1.62 & 1.39 & 0.1632 \\
\hline fenoterol:nifedipine & 0 & 0 & 0.9 & $\mathrm{ND}$ & 0.9 & ND & ND & ND \\
\hline fenoterol:terbutaline & 0 & 0 & 1.16 & ND & 1.16 & ND & $\mathrm{ND}$ & ND \\
\hline nifedipino:terbutaline & 1 & 0.51 & 1.29 & 1.02 & 1.66 & 0.62 & -1.39 & 0.1632 \\
\hline
\end{tabular}

* We present the table with comparisons of each element reported in the column versus the element in every row. In the lower part are the model estimators; the direct tools are in the upper part, when available. The table including differences between direct and indirect estimators for each comparison is also reported with their respective statistical test.

structure of the evidence, $I^{2}$ and the Q test could not be calculated (see Annex 4).

Proportion of maternal adverse events. Five relevant studies were identified for this outcome $(20,21$, 23, 26, 28), for a total of 588 randomized patients; a network meta-analysis was performed (Table 6). Statistically significant differences were found between atosiban and fenoterol $(\mathrm{RR}=0.16$; 95\% CI: 0.08-0.31, moderate certainty), nifedipine $(\mathrm{RR}=0.48 ; 95 \% \mathrm{CI}: 0.3-0.78$, moderate certainty $)$ and terbutaline $(\mathrm{RR}=0.44 ; 95 \% \mathrm{CI}$ : 0.28-0.71, moderate certainty). Similar results were observed in head-to-head comparisons, except the direct comparison between atosiban and terbutaline $(\mathrm{RR}=0.55$; 95\% CI: 0.3-1.00), where point estimation is similar but the confidence interval does not show statistical significance. In this analysis, $\mathrm{I}^{2}$ is $0 \%$, and the intra- and inter-design $p$ values for the $\mathrm{Q}$ test are 0.61 and 0.24 , respectively.

The evidence summary table for the network 


\begin{tabular}{|c|c|c|c|c|c|c|c|c|}
\hline \multicolumn{9}{|c|}{$\begin{array}{c}\text { Table } 4 . \\
\text { Gestational age at the time of delivery" }\end{array}$} \\
\hline \multicolumn{9}{|c|}{ League table } \\
\hline & & \multicolumn{3}{|c|}{ Direct Estimators } & & & & \\
\hline & Atosiban & - & $\begin{array}{c}-0.91 \\
(-3.54-1.71)\end{array}$ & - & & & & \\
\hline \multirow{3}{*}{$\begin{array}{c}\text { Model } \\
\text { estimators }\end{array}$} & $\begin{array}{c}-0.91 \\
(-7.74-5.92)\end{array}$ & Indomethacin & $\begin{array}{c}0.00 \\
(-6.30-6.30)\end{array}$ & - & & & & \\
\hline & $\begin{array}{c}-0.91 \\
(-3.54-1.71)\end{array}$ & $\begin{array}{c}0.00 \\
(-6.30-6.30)\end{array}$ & Nifedipine & $\begin{array}{c}0.78 \\
(-3.33-4.89)\end{array}$ & & & & \\
\hline & $\begin{array}{c}-0.13 \\
(-5.00-4.74)\end{array}$ & $\begin{array}{c}0.78 \\
(-6.74-8.30)\end{array}$ & $\begin{array}{c}0.78 \\
(-3.33-4.89)\end{array}$ & \multicolumn{2}{|l|}{ Terbutaline } & & & \\
\hline \multicolumn{9}{|c|}{ Model estimators, direct and indirect } \\
\hline Comparison & 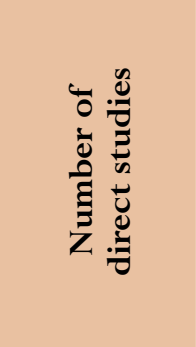 & 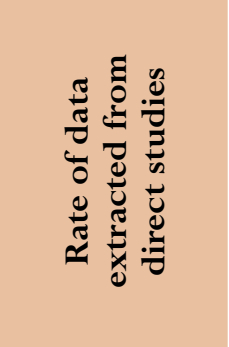 & 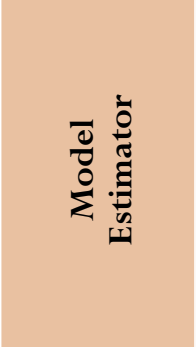 & 莺 & 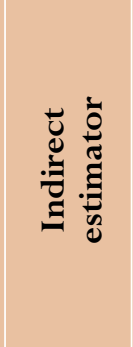 & 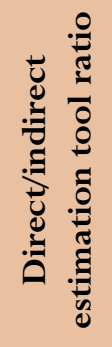 & $\mathbf{N}$ & $\frac{2}{\sum_{2}^{2}}$ \\
\hline atosiban:indometacine & 0 & 0 & -0.9115 & ND & -0.9115 & ND & ND & ND \\
\hline atosiban:nifedipine & 2 & 1 & -0.9115 & -0.9115 & ND & ND & ND & ND \\
\hline atosiban:terbutaline & 0 & 0 & -0.1315 & ND & -0.1315 & ND & ND & ND \\
\hline indometacina:nifedipine & 1 & 1 & 0 & 0 & ND & ND & ND & ND \\
\hline indometacina:terbutaline & 0 & 0 & 0.78 & ND & 0.78 & ND & ND & ND \\
\hline nifedipino:terbutalina & 1 & 1 & 0.78 & 0.78 & ND & ND & ND & ND \\
\hline
\end{tabular}

* We present the table with comparisons of each element reported in the column versus the element in every row. In the lower part are the model estimators; the direct tools are in the upper part, when available. The table including differences between direct and indirect estimators for each comparison is also reported with their respective statistical test.

meta-analysis of this outcome is shown in Annex 4.

Given that aggregate adverse events are considered in this analysis, the broken down information reported in the primary studies is shown below.

Table 7 shows the specific adverse events reported in each study against atosiban, together with the reported statistical analysis. There is evidence of a statistically significant reduction between atosiban and nifedipine in terms of hypotension and overall events (23), a statistically significant reduction between atosiban and terbutaline in terms of tachycardia, tachypnea and dyspnea, and a statistically significant increase between atosiban and terbutaline in terms of nausea, vertigo and hot flashes (26). No reported statistical tests were found for the other outcomes.

For the remaining safety outcomes (neonatal respiratory distress syndrome, intraventricular 


\begin{tabular}{|c|c|c|c|c|c|c|c|c|}
\hline \multicolumn{9}{|c|}{$\begin{array}{c}\text { Table } 5 . \\
\text { Neonatal mortality* }\end{array}$} \\
\hline \multicolumn{9}{|c|}{ League Table } \\
\hline & & \multicolumn{3}{|c|}{ Direct Estimators } & & & & \\
\hline & Atosiban & - & $\begin{array}{c}0.45 \\
(0.19-1.10)\end{array}$ & $\begin{array}{c}0.50 \\
(0.13-1.91)\end{array}$ & & & & \\
\hline & $\begin{array}{c}0.21 \\
(0.05-0.92)\end{array}$ & Indomethacin & $\begin{array}{c}2.20 \\
(0.66-7.30)\end{array}$ & - & & & & \\
\hline \multirow[t]{2}{*}{$\begin{array}{c}\text { Model } \\
\text { Estimators }\end{array}$} & $\begin{array}{c}0.45 \\
(0.19-1.10)\end{array}$ & $\begin{array}{c}2.20 \\
(0.66-7.30)\end{array}$ & Nifedipine & - & & & & \\
\hline & $\begin{array}{c}0.50 \\
(0.13-1.91)\end{array}$ & $\begin{array}{c}2.42 \\
(0.33-17.96)\end{array}$ & $\begin{array}{c}1.10 \\
(0.22-5.48)\end{array}$ & Terbutaline & & & & \\
\hline \multicolumn{9}{|c|}{ Model Estimators, direct and indirect } \\
\hline Comparison & 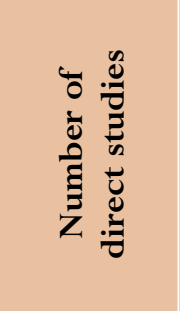 & 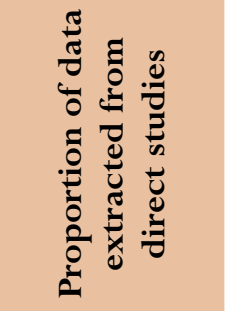 & 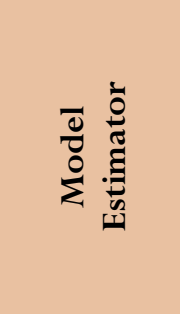 & 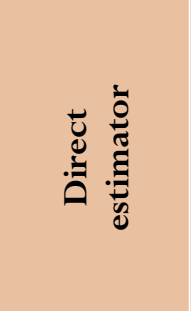 & 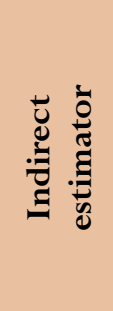 & 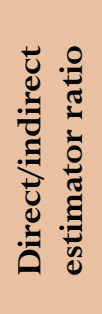 & $\mathbf{N}$ & $\frac{\mathfrak{D}}{\frac{1}{2}}$ \\
\hline atosiban:indomethacin & 0 & 0 & 0.2066 & ND & 0.2066 & ND & ND & ND \\
\hline atosiban:nifedipine & 1 & 1 & 0.4545 & 0.4545 & ND & ND & ND & ND \\
\hline atosiban:terbutaline & 1 & 1 & 0.5 & 0.5 & ND & ND & ND & ND \\
\hline indomethacin:nifedipine & 1 & 1 & 2.2 & 2.2 & ND & ND & ND & ND \\
\hline indomethacin:terbutaline & 0 & 0 & 2.42 & ND & 2.42 & ND & ND & ND \\
\hline nifedipine:terbutaline & 0 & 0 & 1.1 & ND & 1.1 & ND & ND & ND \\
\hline
\end{tabular}

* We present the table with comparisons of each element reported in the column versus the element in every row. In the lower part are the model estimators; the direct tools are in the upper part, when available. The table including differences between direct and indirect estimators for each comparison is also reported with their respective statistical test.

hemorrhage, intraventricular leukomalacia and neonatal complications) a report of the information presented in the primary articles was prepared, considering that there was insufficient information for a network meta-analysis or a simple direct metaanalysis (Table 8). There are no statistically significant differences between atosiban and nifedipine in the four events evaluated. (24) No statistical analysis is reported for the comparison with terbutaline, although a lower frequency of neonatal respiratory distress, intraventricular hemorrhage (25), and total events (26) is reported.

\section{DISCUSSION}

This study is a systematic review of the literature comparing atosiban versus other treatments in patients between 24 and 33 completed weeks of gestation. As far as effectiveness is concerned, no statistically significant differences were found when compared with nifedipine, terbutaline and fenoterol 


\begin{tabular}{|c|c|c|c|c|c|c|c|c|}
\hline \multicolumn{9}{|c|}{$\begin{array}{c}\text { Table } 6 . \\
\text { Maternal adverse events* }\end{array}$} \\
\hline \multicolumn{9}{|c|}{ League table } \\
\hline \multicolumn{9}{|c|}{ Direct estimators } \\
\hline & Atosiban & $\begin{array}{c}0.16 \\
(0.08-0.31)\end{array}$ & $\begin{array}{c}0.39 \\
(0.21-0.71)\end{array}$ & $\begin{array}{c}0.55 \\
(0.30-1.00)\end{array}$ & & & & \\
\hline \multirow{3}{*}{$\begin{array}{l}\text { Model } \\
\text { Estimators }\end{array}$} & $\begin{array}{c}0.16 \\
(0.08-0.31)\end{array}$ & Fenoterol & - & - & & & & \\
\hline & $\begin{array}{c}0.48 \\
(0.30-0.78)\end{array}$ & $\begin{array}{c}3,02 \\
(1.34-6.82)\end{array}$ & Nifedipine & $\begin{array}{c}0.79 \\
(0.48-1.30)\end{array}$ & & & & \\
\hline & $\begin{array}{c}0.44 \\
(0.28-0.71)\end{array}$ & $\begin{array}{c}2.77 \\
(1.23-6.24)\end{array}$ & $\begin{array}{c}0.92 \\
(0.60-1.40)\end{array}$ & Terbutaline & & & & \\
\hline \multicolumn{9}{|c|}{ Model Estimators. direct and indirect } \\
\hline Comparison & 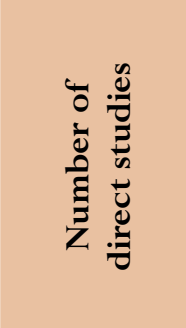 & 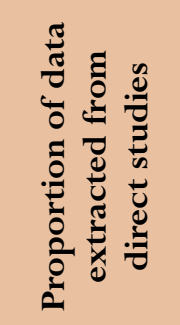 & 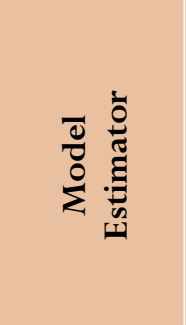 & 导 & 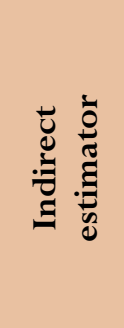 & 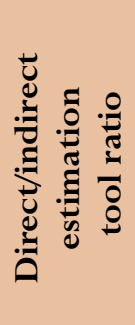 & $\mathbf{N}$ & $\frac{0}{\mathfrak{J}}$ \\
\hline atosiban:fenoterol & 1 & 1 & 0.16 & 0.16 & ND & ND & ND & ND \\
\hline atosiban:nifedipine & 2 & 0.62 & 0.4834 & 0.3874 & 0.6962 & 0.5565 & -1.17 & 0.2422 \\
\hline atosiban:terbutaline & 1 & 0.63 & 0.443 & 0.55 & 0.3061 & 1.7971 & 1.17 & 0.2422 \\
\hline fenoterol:nifedipine & 0 & 0 & 3.0211 & ND & 3.0211 & ND & ND & ND \\
\hline fenoterol:terbutaline & 0 & 0 & 2.7685 & ND & 2.7685 & ND & ND & ND \\
\hline nifedipine:terbutaline & 1 & 0.75 & 0.9164 & 0.79 & 1.4197 & 0.5565 & -1.17 & 0.2422 \\
\hline
\end{tabular}

* We present the table with comparisons of each element reported in the column versus the element in every row. In the lower part are the model estimators; the direct tools are in the upper part, when available. The table including differences between direct and indirect estimators for each comparison is also reported with their respective statistical test.

in terms of no delivery at 48 hours and at 7 days. These results are of moderate-to-low certainty in terms of evidence. When compared to placebo, one study reported significant differences in terms of the composite outcome of no delivery or need for additional tocolytic agents at 48 hours and at 7 days.

Concerning safety, lower neonatal mortality was found for atosiban when compared to indomethacin, and non-significant differences were found with nifedipine and terbutaline (low certainty).
It is worth noting that it was possible to analyze this result from a network with a total of three primary studies. In terms of maternal adverse events, a probably lower frequency was found when compared to fenoterol, nifedipine and terbutaline (moderate certainty). It is worth highlighting that a combined analysis was performed for this outcome, probably combining adverse events of different nature. Consequently, it is reasonable to verify all the comparisons for each event in order 


\begin{tabular}{|c|c|c|c|c|}
\hline \multicolumn{5}{|c|}{$\begin{array}{l}\text { Table } 7 . \\
\text { Maternal adverse event report, by studio }\end{array}$} \\
\hline \multirow[b]{2}{*}{ Studies and comparison } & \multirow[b]{2}{*}{ Outcome } & \multicolumn{2}{|c|}{ Frequency of events, $n(\%)$} & \multirow[t]{2}{*}{$P$ value } \\
\hline & & Atosiban & Reference & \\
\hline \multirow{6}{*}{$\begin{array}{l}\text { Kashanian, Atosiban vs. } \\
\text { nifedipine (20) }\end{array}$} & Headache & $3 / 40(7.5 \%)$ & $3 / 40(7.5 \%)$ & Not reported \\
\hline & Vertigo & $3 / 40(7.5 \%)$ & $9 / 40(22.5 \%)$ & Not reported \\
\hline & Flank pain & $1 / 40(2.5 \%)$ & 0/40 (0\%) & Not reported \\
\hline & Hypotension & $0 / 40(0 \%)$ & $11 / 40(27.5 \%)$ & Not reported \\
\hline & Palpitations & 0/40 (0\%) & $3 / 40(7.5 \%)$ & Not reported \\
\hline & Tachycardia & $0 / 40(0 \%)$ & $3 / 40(7.5 \%)$ & Not reported \\
\hline $\begin{array}{l}\text { Nonnenmacher, atosiban vs. } \\
\text { fenoterol (21) }\end{array}$ & Cardiovascular & $2 / 51(4 \%)$ & $42 / 54(78 \%)$ & Not reported \\
\hline \multirow{10}{*}{$\begin{array}{l}\text { Salim, atosiban vs. } \\
\text { nifedipine ( } 23)\end{array}$} & Hypotension & 2/70 (2.9\%) & $8 / 75(10,7 \%)$ & 0,07 \\
\hline & Tachycardia & $1 / 70(1.4 \%)$ & $3 / 75(5.3 \%)$ & 0,24 \\
\hline & Palpitations & $0 / 70(0 \%)$ & $1 / 75(1.3 \%)$ & Not reported \\
\hline & Headache & $2 / 70(2.9 \%)$ & $4 / 75(5.3 \%)$ & 0,52 \\
\hline & Nausea & 0/70 (0\%) & $1 / 75(1.3 \%)$ & Not reported \\
\hline & Vomiting & $0 / 70(0 \%)$ & $0 / 75(0 \%)$ & Not reported \\
\hline & Itching & $0 / 70(0 \%)$ & $1 / 75(1.3 \%)$ & Not reported \\
\hline & Local reaction & 0/70 (0\%) & 0/75 (0\%) & Not reported \\
\hline & Rash & 0/70 (0\%) & 0/75 (0\%) & Not reported \\
\hline & Any event & $5 / 70(7.1 \%)$ & $17 / 75$ (22.7\%) & 0.01 \\
\hline \multirow{7}{*}{$\begin{array}{l}\text { Cabar, atosiban vs. } \\
\text { terbutaline }(26)\end{array}$} & Tachycardia & 0/40 (0\%) & $20 / 40(50 \%)$ & $<0.05$ \\
\hline & Tachypnea & $0 / 40(0 \%)$ & $5 / 40(12.5 \%)$ & $<0.05$ \\
\hline & Dyspnea & $0 / 40(0 \%)$ & $3 / 40(12.5 \%)$ & $<0.05$ \\
\hline & Nausea & $5 / 40(17.5 \%)$ & 0/40 (0\%) & $<0.05$ \\
\hline & Vertigo & $3 / 40(12.5 \%)$ & 0/40 (0\%) & $<0.05$ \\
\hline & Headache & $2 / 40(5 \%)$ & $2 / 40(5 \%)$ & Not reported \\
\hline & Hot flashes & $1 / 40(2.5 \%)$ & 0/40 (0\%) & $<0.05$ \\
\hline
\end{tabular}

to arrive at a more adequate personalization of the safety profile according to each individual patient. No significant differences were found in terms of neonatal respiratory distress, intraventricular hemorrhage, periventricular leukomalacia and neonatal complications.

How complete was the review in terms of the information obtained in terms of outcomes? Wide screening of 


\begin{tabular}{|c|c|c|c|c|}
\hline \multicolumn{5}{|c|}{$\begin{array}{l}\text { Table } 8 . \\
\text { dies regarding outcomes: Newborn Respiratory } \\
\text { emorrhage, periventricular leukomalacia and total } \\
\text { tal complications }\end{array}$} \\
\hline \multirow[b]{2}{*}{ Study } & \multirow[b]{2}{*}{ Challenge } & \multicolumn{2}{|c|}{$\begin{array}{l}\text { Frequence of events, } \mathbf{n} \\
(\%)\end{array}$} & \multirow[t]{2}{*}{ Reported statistical test } \\
\hline & & Atosiban & Reference & \\
\hline \multicolumn{5}{|c|}{ Newborn Respiratory Distress Syndrome } \\
\hline $\begin{array}{l}\text { European Atosiban study group } 2001 \\
(25)\end{array}$ & Terbutaline & $\begin{array}{l}27 / 131 \\
(20.6 \%)\end{array}$ & $\begin{array}{l}47 / 153 \\
(30.7 \%)\end{array}$ & Not reported \\
\hline Van Vliet* (24) & Nifedipine & $\begin{array}{l}21 / 294 \\
(7 \%)\end{array}$ & $\begin{array}{c}11 / 297 \\
(4 \%)\end{array}$ & $\begin{array}{l}\text { RR of nifedipine vs. } \\
\text { Atosiban } 0.55 \\
\text { (95\% CI: } 0.27-1.15 \text { ) }\end{array}$ \\
\hline \multicolumn{5}{|c|}{ Intraventricular hemorrhage } \\
\hline European Atosiban study group (25) & Terbutaline & $\begin{array}{l}7 / 131 \\
(7.3 \%)\end{array}$ & $\begin{array}{l}13 / 153 \\
(8.5 \%)\end{array}$ & Not reported \\
\hline Van Vliet (24) & Nifedipine & $\begin{array}{l}2 / 294 \\
(1 \%)\end{array}$ & $\begin{array}{l}5 / 297 \\
(2 \%)\end{array}$ & $\begin{array}{l}\text { RR of nifedipine vs. } \\
\text { Atosiban } 2.47 \\
\text { (95\% CI: } 0.48-12.75 \text { ) }\end{array}$ \\
\hline \multicolumn{5}{|c|}{ Periventricular Leukomalacia } \\
\hline Van Vliet (24) & Nifedipine & $\begin{array}{l}2 / 294 \\
(1 \%)\end{array}$ & $\begin{array}{l}1 / 297 \\
(<1 \%)\end{array}$ & $\begin{array}{l}\text { RR of nifedipine vs. } \\
\text { Atosiban } 0.49 \\
\text { (95\% CI: } 0.05-5.46)\end{array}$ \\
\hline \multicolumn{5}{|c|}{ Neonatal Complications } \\
\hline Cabar (26) & Terbutaline & $\begin{array}{c}6 / 40 \\
(15 \%)\end{array}$ & $\begin{array}{c}8 / 40 \\
(20 \%)\end{array}$ & Not reported \\
\hline Van Vliet (24) & Nifedipine & $\begin{array}{l}45 / 294 \\
(15 \%)\end{array}$ & $\begin{array}{l}42 / 297 \\
(14 \%)\end{array}$ & $\begin{array}{l}\text { RR of nifedipine vs. } \\
\text { atosiban } 0.91 \\
(95 \% \mathrm{CI}: 0.61-1.37)\end{array}$ \\
\hline
\end{tabular}

* Bronchopulmonary dysplasia is reported in this study.

the literature is designed to identify all the relevant data available in manuscripts published in journals or registry reports. It may be argued that the limitation in terms of gestational age between 24 and 33 full weeks may have limited the scope of the conclusions of this research, given that it meant that some studies were not included. However, we believe that this makes this review relevant for the local context, given that it focuses on the literature pertaining to the population for which atosiban is indicated in our setting.

Quality of the body of evidence. As reported in the evidence summary tables, the results showed medium-to-low accuracy. Regarding effectiveness outcomes, there are difficulties with the accuracy of the results in the report. They do not allow to differentiate clearly between the absence of a difference and lack of statistical precision for results 
without mathematical significance. For such outcomes it is not considered that within the network there were some open studies.

Regarding the body of evidence available for neonatal mortality, certainty is low. This occurs because of problems related to the accuracy of the tools used for estimation and the structure of the network, which implies that some comparisons come exclusively from first degree loops. For maternal adverse events, the body of evidence is also limited to moderate certainty due to the risk of bias of some open studies that may be relevant both for detection and performance.

Applicability of the results based on the quality of the evidence. Considering all of the above, it may be said that there are no important differences in effectiveness when compared to other active references (moderate certainty). In terms of the results on neonatal mortality, even though they may show interesting information, it is likely that more and better primary evidence is needed to consider them directly for decision making. However, these results should not be ignored. Results on maternal adverse events show a moderate certainty. There is a decrease in such events when compared to other active comparators. This may have implications for clinical practice. A closer look at reported events (Table 7) clearly shows that the decrease in atosiban-related adverse events is cardiovascular, such as hypotension, tachycardia and the like. This is a potentially important aspect since there are cases in which severe hypotension in the mother is associated with an increase in neonatal morbidity and mortality due to the decrease in placental perfusion $(2,31)$. This could imply an assessment by the clinician in order to determine whether the differences in these events may favor atosiban instead of other options. A similar rationale can be used for other reported adverse events.

The main strength of this study is the use of a systematic review methodology for searching and synthesizing available evidence regarding a specific question. The fact that the review considers randomized clinical trials adds to the strength of the body of evidence, because these optimize bias control for intervention questions. The extensive search in medical literature, amplified through the "snowball", attempts to capture all relevant publications even though it cannot ensure absolute certainty. The use of evidence summary tables facilitates communication of results to clinicians. When reviewing meta-analyses available in the literature, none of those obtained in the database search assessed the full amount of the outcomes, or comparison markers of interest for our studies, for which a paper with incremental input to the existing literature could be considered. The population restriction to pregnancies between 24 and 33 complete weeks as indicated by INVIMA may help make the review more relevant from the local perspective.

Regarding its weaknesses, it is worth mentioning that the use of network meta-analyses may create weaknesses in the results, given that indirect evidence is of lower quality than direct evidence, broadly speaking. In this specific case, this effect is not necessarily large, given that in nearly all comparisons there was an important percentage of information coming from direct evidence. In addition, the network structure for some outcomes, such as neonatal mortality, implies many comparisons identical to those in direct studies, while indirect data are used only for notifying some outcomes which had no indirect comparison. The fact that Colombian populations are not included in the trials is a potential, though unavoidable limitation, and it possibly has a marginal effect on the results. The restriction of the population to pregnancies between 24 and 33 complete weeks could be considered as a limitation to the inclusion of relevant studies and generalizing results. This may translate into differences with other previous studies. For 
example, some results differ from those obtained in the meta-analysis carried out by Flenady et al. (32), in which it was observed that there is no evidence suggesting atosiban is superior in terms of extending pregnancy when compared to placebo (32). The difference between the Flenady et al. meta-analysis and this trial may be due to the fact that this metaanalysis included two investigations in patients with gestational age outside the range of interest for the present study and outside the one set forth in the health registry. In this case, the information from the composite outcome resulting exclusively from a primary trial was included, which could limit the utility of this conclusion. However, it is useful because it sheds light on a potentially favorable effect of atosiban over placebo.

\section{CONCLUSIONS}

Atosiban probably shows no differences in effectiveness when compared to nifedipine, terbutaline and fenoterol in terms of labor delay at 48 hours and 7 days in pregnant women with risk of preterm labor between 24 and 33 weeks (moderate to low certainty). The comparison of atosiban against placebo based on a primary study, showing a possible improved performance of atosiban in terms of a composite outcome of labor delay and non use of tocolysis at 48 hours and at 7 days.

Regarding safety, there is possibly a lower frequency of events with atosiban when compared to indomethacin, whereas no statistically significant differences were found with nifedipine and terbutaline (low certainty).

Concerning maternal adverse events, potential reduction of events was found with atosiban compared to fenoterol, nifedipine and terbutaline. It is worth looking closely at the differences regarding specific adverse events versus each comparator to assess whether these have an impact on clinical behavior.

\section{FUNDING}

Funding from Biopas S.A. was received for this study.

\section{REFERENCES}

1. Iragorri V, Rodríguez Donado A, Perdomo Suarez D. Guía de manejo de trabajo de parto pretérmino. Secretaría Distrital de Salud. Bogotá: Asociación Bogotana de Obstetricia y Ginecología; 2013.

2. Lamont CD, Jørgensen JS, Lamont RF. The safety of tocolytics used for the inhibition of preterm labour. Expert Opin Drug Saf. 2016;15:1163-73. https://doi. org/10.1080/14740338.2016.1187128

3. Blencowe H, Cousens S, Oestergaard MZ, Chou D, Moller AB, Narwal R, et al. National, regional, and worldwide estimates of preterm birth rates in the year 2010 with time trends since 1990 for selected countries: A systematic analysis and implications. Lancet. 2012;379:2162-72. https://doi.org/10.1016/ S0140-6736(12)60820-4

4. Beck S, Wojdyla D, Say L, Pilar Bertran A, Meraldi M, Harris Requejo J, et al. The worldwide incidence of preterm birth: A systematic review of maternal mortality and morbidity. Bull World Health Organ. 2010;88:31-8. https://doi.org/10.2471/ BLT.08.062554

5. Departamento Administrativo Nacional de Estadística (DANE). Nacimientos 2016; 2017.

6. Voto L, Valenti E, Asprea I, Voto G, Votta R. Parto pretérmino. FAGO. 2014;13:5-10.

7. Lawn JE, Cousens S, Zupan J, Lancet Neonatal Survival Steering Team. 4 million neonatal deaths: When? Where? Why? Lancet. 2005;365:891-900.

8. Fellman V, Hellström-Westas L, Norman M, Westgren M, Källén K, Lagercrantz $\mathrm{H}$, et al. One-year survival of extremely preterm infants after active perinatal care in Sweden. Jama. 2009;301:2225-33. https:// doi.org/10.1001/jama.2009.771

9. Odibo IN, Bird TM, McKelvey SS, Sandlin A, Lowery C, Magann EF. Childhood respiratory morbidity 
after late preterm and early term delivery: A study of medicaid patients in South Carolina. Paediatr Perinat Epidemiol. 2016;30:67-75. https://doi.org/10.1111/ ppe. 12250

10. Mendoza AL, Claros DI, Mendoza LI, Arias MD, Pearanda CB. Epidemiología de la prematuridad, sus determinantes y prevención del parto prematuro. Rev Chil Obs Ginecol. 2016;81:330-42. https://doi. org/10.4067/S0717-75262016000400012

11. Sociedad Española de Ginecología y Obstetricia. Amenaza de parto pretérmino. Progresos Obstet y Ginecol. 2012;55:347-66.

12. Kam KYR, Lamont RF. Developments in the pharmacotherapeutic management of spontaneous preterm labor. Expert Opin Pharmacother. 2008;9:1153-68. https://doi.org/10.1517/14656566.9.7.1153

13. Lamont RF. The development and introduction of antioxytocic tocolytics. BJOG An Int J Obstet Gynaecol. 2003;110:108-12. https://doi.org/10.1046/j.14710528.2003.00055.x

14. Schleußner E. The prevention, diagnosis and treatment of premature labor. Dtsch Ärzteblatt Int. 2013;110:227-35; quiz 236.

15. Higgins JPT, Altman DG, Gotzsche PC, Juni P, Moher D, Oxman AD, et al. The Cochrane Collaboration's tool for assessing risk of bias in randomised trials. BMJ. 2011;343:d5928-d5928.

16. Schuneman H, Brozek J, Guyatt G, Oxman A. GRADE Handbook. 2013 (visited 2018 oct 31). Available in: https://gdt.gradepro.org/app/handbook/handbook. html

17. Brignardello-Petersen R, Bonner A, Alexander PE, Siemieniuk RA, Furukawa TA, Rochwerg B, et al. Advances in the GRADE approach to rate the certainty in estimates from a network meta-analysis. J Clin Epidemiol. 2018;93:36-44. https://doi.org/10.1016/j. jclinepi.2017.10.005

18. Higgins J, Green S. 9.5.2 Identifying and measuring heterogeneity. 2011 (visited 2018 oct 31). Available in: https://handbook-5-1.cochrane.org/ chapter_9/9_5_2_identifying_and_measuring_heterogeneity.htm
19. Ministerio de Salud y Protección Social. Resolución 8430 de 1993.

20. Kashanian M, Akbarian AR, Soltanzadeh M. Atosiban and nifedipin for the treatment of preterm labor. Int J Gynaecol Obstet. 2005;91:10-4. https://doi. org/10.1016/j.ijgo.2005.06.005

21. Nonnenmacher A, Hopp HDJ. Wirksamkeit und sicherheit von Atosiban vs. pulsatiler applikation von fenoterol bei der behandlung vorzeitiger wehen. $\mathrm{Z}$ Geburtshilfe Neonatol. 2009;213:201-6. https://doi. org/10.1055/s-0029-1225640

22. Romero R, Sibai B, Sanchez-Ramos L, Valenzuela G, Veille J, Tabor B. An oxytocin receptor antagonist (atosiban) in the treatment of preterm labor: A randomized, double-blind, placebo-controlled trial with tocolytic rescue. Am J Obstet Gynecol. 2000;182:1173-83. https://doi.org/10.1067/ mob.2000.95834

23. Salim R, Garmi G, Nachum Z, Zafran N, Baram S, Shalev E. Nifedipine compared with atosiban for treating preterm labor: A randomized controlled trial. Obstet Gynecol. 2012;120:1323-31. https:// doi.org/10.1097/AOG.0b013e3182755dff

24. van Vliet E, Nijman T, Schuit E, Heida KY, Opmeer BC, Kook M. Nifedipine versus atosiban for threatened preterm birth (APOSTEL III): A multicentre, randomised controlled trial. Lancet. 2016;387:2117-24. https://doi.org/10.1016/S0140-6736(16)00548-1

25. European Atosiban Study Group. The oxytocin antagonist atosiban versus the beta-agonist terbutaline in the treatment of preterm labor. A randomized, double-blind, controlled study. Acta Obstet Gynecol Scand. 2001;80:413-22.

26. Cabar FR, Bittar RE, Gomes CM, Zugaib M. O atosibano como agente tocolítico: Uma nova proposta de esquema terapêutico. Rev Bras Ginecol Obstet. 2008;30:87-92. https://doi.org/10.1590/S010072032008000200007

27. Klauser C, Briery C, Keiser S, Martin R, Kosek M, Morrison J. Effect of antenatal tocolysis on neonatal outcomes. J Matern Fetal Neonatal Med. 2012;25:2778-81. https://doi.org/10.3109/147670 58.2012 .714819 
28. Mawaldi L, Duminy P, Tamim H. Terbutaline versus nifedipine for prolongation of pregnancy in patients with preterm labor. Int J Gynaecol Obstet. 2008;100:65-8. https://doi.org/10.1016/j. ijgo.2007.06.047

29. Valdés E, Salinas H, Toledo V, Lattes K, Cuellar E, Perucca $\mathrm{E}$, et al. Nifedipine versus fenoterol in the management of preterm labor: A randomized, multicenter clinical study. Gynecol Obstet Invest. 2012;74:109-15. https://doi.org/10.1159/000338856
30. Weerakul W, Chittacharoen A, Suthutvoravut S. Nifedipine versus terbutaline in management of preterm labor. Int J Gynaecol Obstet. 2002;76:311-3. https:// doi.org/10.1016/S0020-7292(01)00547-1

31. Page A, Page GH. Tocolysis in 2016: An evidencebased clinical review. Int J Obstet Gynaecol Res. 2016;3:462-73.

32. Flenady V, Reinebrant HE, Liley HG, Tambimuttu EG, Papatsonis DNM. Oxytocin receptor antagonists for inhibiting preterm labour (review). Cochrane Database Syst Rev. 2014;3(6).

\section{Conflict of interest: This paper was financed by Biopas laboratory, manufacturer of the product.} The authors declare the criteria were independent and the laboratory had no role in data collection, analysis or interpretation of results, or in the preparation of this manuscript. 


\section{ANNEXES}

\section{Annex 1.}

Research strategies and results for each database

\begin{tabular}{|c|c|}
\hline & Research report \# 1 \\
\hline Type of search & New \\
\hline Database & Medline \\
\hline Platform & PubMed \\
\hline Search date & 08/06/2017 \\
\hline Date of search range & No restriction \\
\hline Language restrictions & None \\
\hline Other limits & None \\
\hline $\begin{array}{l}\text { Research strategy } \\
\text { (results) }\end{array}$ & 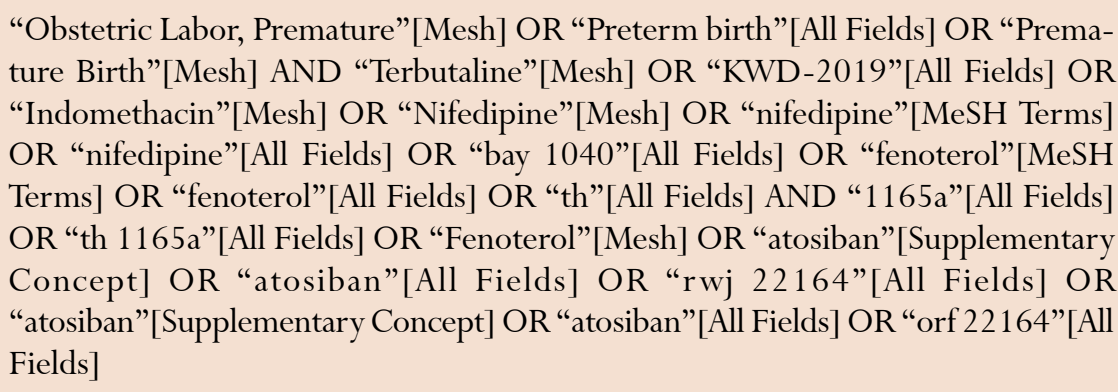 \\
\hline References identified & 1097 \\
\hline References without duplicates & 1074 \\
\hline
\end{tabular}

\section{Research report \# 2}

\begin{tabular}{|c|c|}
\hline Type of search & New \\
\hline Databases & EMBASE \\
\hline Platform & Elsevier \\
\hline Date of research & 08/06/2017 \\
\hline Search date range & No restrictions \\
\hline Language restrictions & None \\
\hline Other limitations & None \\
\hline Search strategy (results) & $\begin{array}{l}\text { "prematurity"/exp OR “premature labor"/exp AND (“fenoterol”/exp OR “ato- } \\
\text { siban"/exp OR “indomethacin"/exp OR “terbutaline"/exp OR “nifedipine”/exp } \\
\text { OR “terbutaline sulfate"/exp) }\end{array}$ \\
\hline References identified & 3958 \\
\hline References without duplicates & 3894 \\
\hline
\end{tabular}




\section{Research report \# 3}

\begin{tabular}{l|l}
\hline Type of search & New \\
\hline Databases & Cochrane Database of Systematic Reviews \\
\hline Platform & Wiley \\
\hline Date of research & $08 / 06 / 2017$ \\
\hline Search date range & No restrictions \\
\hline Language restrictions & None \\
\hline Other limitations & None \\
\hline Search strategy (results) & "Preterm birth" OR "Premature Birth" AND "Terbutaline" OR KWD-2019 OR \\
"Indomethacin" OR "Nifedipine" OR bay 1040 OR th 1165a OR Fenoterol OR \\
"atosiban" OR rwj 22164 OR orf 22164
\end{tabular}

\section{Research report \# 4}

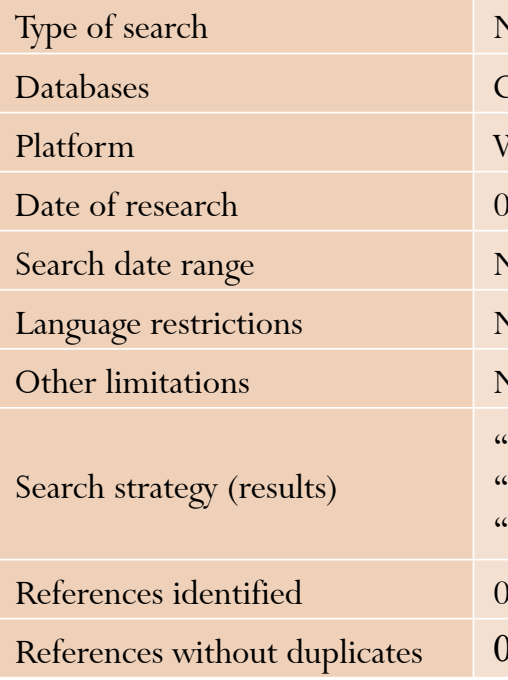

New

Cochrane Database of Abstracts of Reviews of Effects (DARE)

Wiley

08/06/2017

No restrictions

None

None

"Preterm birth" OR "Premature Birth" AND "Terbutaline" OR KWD-2019 OR "Indomethacin" OR "Nifedipine" OR bay 1040 OR th 1165a OR Fenoterol OR "atosiban” OR rwj 22164 OR orf 22164

0

0

\begin{tabular}{|l|l|}
\hline & \multicolumn{1}{c}{ Research report \# 5} \\
\hline Type of search & New \\
\hline Databases & Cochrane Central Register of Controlled Trials - CENTRAL \\
\hline Platform & Ovid \\
\hline Date of research & $08 / 06 / 2017$ \\
\hline Search date range & No restrictions \\
\hline Language restrictions & None \\
\hline Other limitations & None \\
\hline Search strategy (results) & $\begin{array}{l}\text { "Preterm birth" OR "Premature Birth" AND “Terbutaline" OR KWD-2019 OR } \\
\text { "Indomethacin" OR "Nifedipine" OR bay 1040 OR th 1165a OR Fenoterol OR } \\
\text { "atosiban" OR rwj 22164 OR orf 22164 }\end{array}$ \\
\hline References identified & 173 \\
\hline References without duplicates & 171 \\
\hline
\end{tabular}




\section{Research report \# 6}

Type of search
Databases
Platform
Date of research
Search date range
Language restrictions
Other limitations
Search strategy (results)
References identified
References without duplicates

New

Lilacs

Virtual health library (VHL)

08/06/2017

No restrictions

None

None

tw:Preterm birth OR Premature AND tw:Terbutaline OR tw: Indomethacin OR tw: Nifedipine OR tw: Fenoterol OR tw: atosiban

32

32

\section{Research report \# 7}

\begin{tabular}{l|l}
\hline Type of search & New \\
\hline Databases & WHO International Clinical Trials Registry \\
\hline Platform & ICTRP portal \\
\hline Date of research & $08 / 06 / 2017$ \\
\hline Search date range & No restrictions \\
\hline Language restrictions & None \\
\hline Other limitations & None \\
\hline Search strategy (results) & $\begin{array}{l}\text { Preterm birth OR Premature Birth AND Terbutaline OR KWD-2019 OR Indo- } \\
\text { methacin OR Nifedipine OR bay 1040 OR th 1165a OR Fenoterol OR atosiban } \\
\text { OR rwj 22164 OR orf 22164 }\end{array}$ \\
\hline References identified & 2 \\
\hline References without duplicates & 2 \\
\hline
\end{tabular}

\section{Research report \# 8}

\begin{tabular}{l} 
Type of search \\
Databases \\
Platform \\
Date of research \\
Search date range \\
\hline Language restrictions \\
\hline Other limitations \\
\hline Search strategy (results) \\
References identified \\
References without duplicates
\end{tabular}

New

ClinicalTrials.gov

$08 / 06 / 2017$

No restrictions

None

None

Preterm birth OR Premature Birth AND Terbutaline OR KWD-2019 OR Indomethacin OR Nifedipine OR bay 1040 OR th 1165a OR Fenoterol OR atosiban OR rwj 22164 OR orf 22164

66

66 
Annex 2.

Description of included trials

\begin{tabular}{|c|c|c|}
\hline Author / year & Cabar (24) & European (23) \\
\hline Type of study & Randomized clinical Trial & Randomized clinical Trial \\
\hline $\begin{array}{l}\text { Comparison/ } \\
\text { Challenge }\end{array}$ & Atosiban vs. Terbutaline & Atosiban vs. Terbutaline \\
\hline \multirow{3}{*}{ Dose } & $\begin{array}{l}\text { Atosiban bolus } 6,75 \mathrm{mg} \text {, inf } 300 \mu \mathrm{g} \\
\min \times 3-5 \mathrm{~h}, 100 \mu \mathrm{g} / \min \times 3.5 \mathrm{~h}\end{array}$ & $\begin{array}{l}\text { Atosiban bolus } 6,75 \mathrm{mg} \text {, inf } 300 \mu \mathrm{g} / \min \times 3 \mathrm{~h}, 100 \\
\mu \mathrm{g} / \min \times 18 \mathrm{~h}\end{array}$ \\
\hline & & \\
\hline & $\begin{array}{l}\text { Terbutaline } 2,5 \mathrm{mg} \text { infusión en } 500 \\
\mathrm{~mL} \text { glucose } 5 \%(20 \mathrm{~mL} / \mathrm{h})\end{array}$ & Terbutaline $10-25$ ug in dextrose at $5 \%$ \\
\hline Type of analysis & Intention to treat & - \\
\hline Sample size & 80 & 249 \\
\hline Location & São Paulo, Brazil & Czech Republic, Denmark, Sweden, United Kingdom \\
\hline Inclusion criteria & $\begin{array}{l}\text { Patients with singleton pregnancy, } \\
\text { gestational age } 23-33 \text { weeks plus } 6 \\
\text { days, intact membranes, live fetus, } \\
\text { no maternal comorbidities, no } \\
\text { fetoplacental disease condition, no } \\
\text { intrauterine growth restriction, no } \\
\text { fetal distress, no cervical incom- } \\
\text { petence, with amniotic fluid index } \\
\text { between } 5 \text { and } 25\end{array}$ & $\begin{array}{l}\text { Patients over } 18 \text { years of age with a gestational age be- } \\
\text { tween } 23-33 \text { full weeks, with preterm labor defined as } \\
\text { the presence of } 4 \text { or morecontractions over a } 30 \text {-minute } \\
\text { time period lasting } 30 \text { or more seconds, } 0-3 \mathrm{~cm} \text { or } 1-3 \\
\mathrm{~cm} \text { of cervical dilation in nulliparous and multiparous } \\
\text { women, respectively, and effacement greater than } 50 \%\end{array}$ \\
\hline Exclusion criteria & Not reported & $\begin{array}{l}\text { Multiple gestation, rupture of membranes, vaginal } \\
\text { bleeding, use of NSAIDs for tocolysis in the previous } \\
12 \text { hours, severe preeclampsia or hypertension, body } \\
\text { temperature higher than } 37.5^{\circ} \mathrm{C} \text {, urinary infection, } \\
\text { fetoplacental abnormalities, maternal comorbidities, } \\
\text { contraindications for the use of terbutaline, alcohol } \\
\text { or psychoactive substances use, hypersensitivity to } \\
\text { the study agent, participation in a clinical trial in the } \\
\text { previous month }\end{array}$ \\
\hline Average age & 28,4 years & -- \\
\hline $\begin{array}{l}\text { Ovular membrane } \\
\text { status }\end{array}$ & Intact & Intact \\
\hline $\begin{array}{l}\text { Gestational age at } \\
\text { the start of tocolysis }\end{array}$ & 23-33,6 weeks & 23-33 complete weeks \\
\hline $\begin{array}{l}\text { Gestational age at } \\
\text { delivery }\end{array}$ & 28-40 weeks & 35 weeks \\
\hline Type of pregnancy & Single & Singleton and multiple \\
\hline
\end{tabular}




\begin{tabular}{|l|l|}
\hline \multicolumn{1}{|c|}{ Author / year } & \multicolumn{1}{c|}{ Cabar (24) } \\
\hline \multirow{2}{*}{ Outcomes } & Time of delivery delay \\
\hline & Maternal adverse events \\
\hline Ethical approval & $\begin{array}{l}\text { Neonatal complications } \\
\text { Project analysis (CAPPesq) of HC- } \\
\text { FMUSP }\end{array}$ \\
\hline
\end{tabular}

Maternal adverse events

Neonatal complications that required NICU

Ethics Committee for each institution and in accordance with the declaration of Helsinki

\begin{tabular}{|c|c|c|}
\hline Author / year & Mawaldi (26) & Klauser (25) \\
\hline Type of study & Randomized clinical trial & Randomized clinical trial \\
\hline Comparisons & Terbutaline, Nifedipine & $\begin{array}{l}\text { Indomethacin, magnesium sulphate, } \\
\text { nifedipine }\end{array}$ \\
\hline \multirow{3}{*}{ Dose } & $\begin{array}{l}\text { Terbutaline, } 0.25 \mathrm{mg} \text { loading dose, } \\
\text { repeat every } 45 \text { minutes }\end{array}$ & $\begin{array}{l}\text { Indomethacin } 100 \mathrm{mg} \text {, followed by } 50 \\
\mathrm{mg} \text { every } 6 \mathrm{~h} \max 48 \mathrm{~h}\end{array}$ \\
\hline & $\begin{array}{l}\text { Nifedipine } 30 \mathrm{mg} \text { initial dose, } 20 \mathrm{mg} \\
\text { at } 90 \mathrm{~min} \text { followed by } 20 \mathrm{mg} \text { every } 8 \\
\mathrm{~h} \text { for } 48 \mathrm{~h}\end{array}$ & $\begin{array}{l}\text { Magnesium sulphate } 6 \mathrm{~g} \text {, maintenance } \\
4-6 \mathrm{~g} / \mathrm{h} \text {, followed by } 20-30 \mathrm{mg} \text { every } \\
4-6 \mathrm{~h}\end{array}$ \\
\hline & & Nifedipine \\
\hline Type of analysis & Intention to treat & NA \\
\hline Sample size & Terbutaline 95, nifedipine 79 & $\begin{array}{l}\text { Indomethacin } 34 \text {, magnesium sulphate } \\
\text { 33, nifedipine } 42\end{array}$ \\
\hline Location & Saudi Arabia & United States \\
\hline Inclusion criteria & $\begin{array}{l}\text { Patients with gestational age between } \\
24 \text { and } 34 \text { weeks with } 1 \text { to } 3 \text { uterine } \\
\text { contractions in } 10 \text { min for } 1 \mathrm{~h} \text {, cervix } \\
\text { dilation at } 0-3 \mathrm{~cm} \text { for first pregnancies } \\
\text { and } 1-3 \mathrm{~cm} \text { for multiparous women, } \\
\text { cervical effacement under } 50 \%\end{array}$ & $\begin{array}{l}\text { Patients with gestational age between } \\
20 \text { and } 32 \text { weeks with risk of preterm } \\
\text { delivery, integral membranes, single } \\
\text { pregnancies or twin pregnancies, cervix } \\
\text { dilation } 1 \text { to } 6 \mathrm{~cm} \text { and cervix effacement. }\end{array}$ \\
\hline Exclusion criteria & $\begin{array}{l}\text { Pregnancies with more than } 2 \text { fetu- } \\
\text { ses, severe hemorrhage, membrane } \\
\text { ruptures, maternal comorbidities, } \\
\text { temperature greater than } 37.5^{\circ} \mathrm{C} \text {, } \\
\text { hypotension, major malformations. }\end{array}$ & $\begin{array}{l}\text { Preeclampsia, abruptio placentae, major } \\
\text { fetal malformations, chorioamnionitis, } \\
\text { intrauterine growth restriction, fetal } \\
\text { suffering. }\end{array}$ \\
\hline Average age & $\begin{array}{l}\text { Terbutaline } 25.3 \text { (5.6), nifedipine } \\
25.4(5.8)\end{array}$ & NA \\
\hline Ovular membranes & Intact & Intact \\
\hline
\end{tabular}




\begin{tabular}{|c|c|c|c|c|}
\hline \multicolumn{2}{|c|}{ Author / year } & \multicolumn{2}{|c|}{ Mawaldi (26) } & \\
\hline \multicolumn{2}{|c|}{$\begin{array}{l}\text { Gestational age at the start } \\
\text { of tocolysis }\end{array}$} & \multicolumn{2}{|c|}{$\begin{array}{l}\text { Terbutaline } 30.6 \text { (2.4), Nifedipine } \\
30.4(2.1)\end{array}$} & NA \\
\hline \multicolumn{2}{|c|}{$\begin{array}{l}\text { Gestational Age at the start } \\
\text { of delivery }\end{array}$} & \multicolumn{2}{|l|}{ NA } & $\begin{array}{l}\text { Indom } \\
\text { sulphat }\end{array}$ \\
\hline \multicolumn{2}{|l|}{ Type of gestation } & \multicolumn{2}{|c|}{$\begin{array}{l}\text { Terbutaline: singleton } 83(87.4) \text {, } \\
\text { twin } 12(12.6) \text {, Nifedipine: single } 67 \\
(84.8), \text { twin } 12(15.2)\end{array}$} & $\begin{array}{l}\text { Twin: } \\
\text { sulphat }\end{array}$ \\
\hline \multicolumn{2}{|l|}{ Outcomes } & \multicolumn{2}{|c|}{$\begin{array}{l}\text { Prolongation of pregnancy, delivery } \\
\text { at } 48 \mathrm{~h} \text {, complications after } 3 \mathrm{~h} \text { of } \\
\text { treatment }\end{array}$} & $\begin{array}{l}\text { Neonat } \\
\text { require } \\
\text { newbor }\end{array}$ \\
\hline \multicolumn{2}{|l|}{ Ethical Approval } & \multicolumn{2}{|c|}{$\begin{array}{l}\text { Ethics Committee of King Abdulaziz } \\
\text { Medical City Research }\end{array}$} & Not re \\
\hline \multicolumn{2}{|l|}{ Financing } & \multicolumn{2}{|l|}{ Not reported } & No rep \\
\hline Author / year & \multicolumn{2}{|c|}{ Valdes (27) } & \multicolumn{2}{|l|}{ Weerakul (28) } \\
\hline Type of study & \multicolumn{2}{|c|}{ Randomized clinical trial } & \multicolumn{2}{|c|}{ Randomized clinical trial } \\
\hline Comparisons & \multicolumn{2}{|c|}{ Nifedipine, fenoterol } & \multicolumn{2}{|l|}{ Nifedipine, terbutaline } \\
\hline \multirow{2}{*}{ Dose } & \multicolumn{2}{|c|}{$\begin{array}{l}\text { Nifedipine } 20 \mathrm{mg} \text { initially } \\
\text { with a possibility to readmi- } \\
\text { nister up until } 60 \mathrm{mg} \text { in } 1 \mathrm{~h} \text {. } \\
\text { Maintenance dose of } 20 \mathrm{mg} \\
\text { every } 6 \mathrm{~h} .\end{array}$} & \multicolumn{2}{|c|}{$\begin{array}{l}\text { nifedipine initial dose } 10 \mathrm{mg} \\
\text { with repetition cada } 30 \mathrm{~min} \\
\text { up until } 40 \mathrm{mg} \text {. Maintenance } \\
\text { dose between } 60-120 \mathrm{mg} / \text { day }\end{array}$} \\
\hline & \multicolumn{2}{|c|}{$\begin{array}{l}\text { Fenoterol } 1 \mu \mathrm{g} / \mathrm{min} \text { initial } \\
\text { dose, maximum } 4 \mu \mathrm{g} / \mathrm{min} \text {. } \\
\text { Maintenance dose } 0,5-1 \\
\mu \mathrm{g} / \mathrm{min}\end{array}$} & \multicolumn{2}{|c|}{$\begin{array}{l}\text { Terbutaline initial dose } 0.25 \\
\mu \mathrm{g} \text {, maintenance } 5 \mu \mathrm{g} / \mathrm{min} \\
\text { maximum } 15 \mu \mathrm{g} / \mathrm{min}\end{array}$} \\
\hline Type of analysis & \multicolumn{2}{|c|}{ Intention to treat } & \multicolumn{2}{|l|}{ Intention to treat } \\
\hline Sample size & \multicolumn{2}{|l|}{132} & \multicolumn{2}{|l|}{89} \\
\hline Location & \multicolumn{2}{|l|}{ Chile } & \multicolumn{2}{|l|}{ Bangkok, Thailand } \\
\hline $\begin{array}{l}\text { Inclusion } \\
\text { criteria }\end{array}$ & \multicolumn{2}{|c|}{$\begin{array}{l}\text { Singleton pregnancy, pa- } \\
\text { tients with risk of preterm } \\
\text { delivery, gestational age } \\
\text { between } 22 \text { and } 34 \text { weeks } \\
\text { with integral membranes. }\end{array}$} & \multicolumn{2}{|c|}{$\begin{array}{l}\text { Patients with risk of preterm } \\
\text { delivery and gestational age } \\
\text { between } 28 \text { and } 34 \text { complete } \\
\text { weeks. }\end{array}$} \\
\hline
\end{tabular}

Atosiban: bolus infusion at 6.25 $\mathrm{mg}$, followed by $300 \mu \mathrm{g} / \mathrm{min}$ infusion for $3 \mathrm{~h}$ and then $100 \mu \mathrm{g}$-min for up to 45 hours; Placebo: equal volumes and flow rate as atosiban

\author{
Intention to treat \\ Atosiban 246, placebo 255 \\ United States
}

Patients with risk of preterm delivery with intact membranes and cervical dilation under $3 \mathrm{~cm}$ in pregnancies between 20 weeks and 33 weeks plus 6 days 


\begin{tabular}{|c|c|c|c|}
\hline Author / year & Valdes (27) & Weerakul (28) & Romero (22) \\
\hline $\begin{array}{l}\text { Exclusion } \\
\text { criteria }\end{array}$ & $\begin{array}{l}\text { Intrauterine infection, ma- } \\
\text { jor fetal malformations, } \\
\text { abruptio placentae, intra- } \\
\text { uterine growth restriction, } \\
\text { counterindications for to- } \\
\text { colysis therapy, rupture pf } \\
\text { membranes }\end{array}$ & Not reported & $\begin{array}{l}\text { Presence of fetal or placental } \\
\text { abnormalities, suboptimal fetal } \\
\text { status, clinical suspicion of cho- } \\
\text { rioamnionitis, maternal indica- } \\
\text { tions for delivery, urinary tract } \\
\text { infection, clinical manifestations } \\
\text { of substance abuse }\end{array}$ \\
\hline Average age & $\begin{array}{l}\text { Nifedipine } 26.2(6.1) \text {, Fe- } \\
\text { noterol } 25.5(6.9)\end{array}$ & $\begin{array}{l}\text { Nifedipine } 27.96(4.78) \text {, } \\
\text { Terbutaline 28,52 (5.34) }\end{array}$ & Not reported \\
\hline $\begin{array}{l}\text { Ovular } \\
\text { membranes }\end{array}$ & Intact & Intact & Intact \\
\hline $\begin{array}{l}\text { Gestational age } \\
\text { at the start of } \\
\text { tocolysis }\end{array}$ & $\begin{array}{l}\text { Nifedipine } 31.7(2.7) \text {, } \\
\text { Fenoterol } 31.2(2.4)\end{array}$ & $\begin{array}{l}\text { Nifedipine } 31.8(1.49) \text {, } \\
\text { Terbutaline } 31.18(2.5)\end{array}$ & $\begin{array}{l}\text { Atosiban } 30.3 \text { (3.07), placebo } \\
31.0(2.52)\end{array}$ \\
\hline $\begin{array}{l}\text { Gestational age } \\
\text { at the start of } \\
\text { delivery }\end{array}$ & NA & NA & Not reported \\
\hline $\begin{array}{l}\text { Type of } \\
\text { pregnancy }\end{array}$ & NA & NA & $\begin{array}{l}\text { Atosiban single dose } 210 / 246 \\
\text { multiple dose } 36 / 246 \text {, placebo } \\
\text { single } 212 / 255 \text {, multiple } 43 / 255\end{array}$ \\
\hline $\begin{array}{l}\text { Assessed } \\
\text { outcomes }\end{array}$ & $\begin{array}{l}\text { Effectiveness of tocolytic } \\
\text { agent as first line treatment. } \\
\text { Delivery before } 24 \mathrm{~h} \text {, bet- } \\
\text { ween } 24 \text { and } 48 \text { h, after } 48 \\
\text { h, after } 7 \text { days. Prolongation } \\
\text { of pregnancy. Maternal ad- } \\
\text { verse events. Discontinua- } \\
\text { tion of medication. Perina- } \\
\text { tal and neonatal outcomes. }\end{array}$ & $\begin{array}{l}\text { Prolongation of delivery, deli- } \\
\text { very after } 48 \text { h, delivery before } \\
\text { week } 34 \text {, delivery after week } \\
37 \text {, gestational age at birth, } \\
\text { weight at birth. }\end{array}$ & $\begin{array}{l}\text { Time to therapeutic failure or } \\
\text { delivery, percentage of successful } \\
\text { treatment at } 24 \text { hours, } 48 \text { hours } \\
\text { and } 7 \text { days, maternal and fetal } \\
\text { adverse events. }\end{array}$ \\
\hline $\begin{array}{l}\text { Ethical } \\
\text { approval }\end{array}$ & Not reported & Not reported & $\begin{array}{l}\text { Approval of each participating } \\
\text { institution }\end{array}$ \\
\hline Funding & $\begin{array}{l}\text { National Fund for Health } \\
\text { Research }\end{array}$ & Not reported & Not reported \\
\hline
\end{tabular}




\section{Annex 3.}

\section{References excluded and reasons for exclusion}

1. Al-Omari WR, Al-Shammaa HB, Al-Tikriti EM, Ahmed KW. Atosiban and nifedipine in acute tocolysis: A comparative study. Eur J Obstet Gynecol Reprod Biol. 2006; 128(1):129-34. Razón de exclusión: no cumple con los criterios de la población estudiada. Incluye pacientes desde la semana 24 hasta la semana 35.

2. Cárcamo JA, Flores E. Nifedipina: una opción en uteroinhibición comparado con el uso de Fenoterol. Rev Med Hondur. 1998;66(1):12-6. Razón de exclusión: incluye pacientes con edad gestacional fuera del rango de interés.

3. Goodwin TM, Valenzuela G, Silver H, Creasy G. Atosiban Study Group: Dose ranging study of the oxytocin antagonist atosiban in the treatment of preterm labor. Obstet Gynecol. 1996;88(3):331-6. Razón de exclusión: no cumple con los criterios de la población estudiada. Incluye pacientes desde la semana 24 hasta la 34.

4. Goodwin TM, Paul R, Silver H, Spellacy W, Parsons M, Chez R, et al. The effect of the oxytocin antagonist atosiban on preterm uterine activity in the human. Am J Obstet Gynecol. 1994;170(2):474-8. Razón de exclusión: no cumple con los criterios de la población estudiada. Incluye pacientes desde la semana 26 hasta la semana 36.

5. Helmer H, Husslein P. Inhibition of premature labor with atosiban. Geburtshilfe und frauenheilkunde. 2003;63(7):687-9. Razón de exclusión: no incluye población de interés.

6. Husslein P, Cabero Roura L, Dudenhausen JW, Helmer H, Frydman R, Rizzo N, et al. Atosiban versus usual care for the management of preterm labor. J Perinat Med. 2007;35(4):305-13. Razón de exclusión: no hacen análisis diferenciado entre atosiban y el tratamiento usual (b-agonistas, calcio antagonistas, sulfato de magnesio, otros tocolíticos o reposo en cama).

7. Klauser CK, Briery CM, Tucker AR, Martin RW, Magann EF, Chauhan SP, et al. Tocolysis in women with advanced preterm labor: A secondary analysis of a randomized clinical trial. J Matern Fetal Neonatal Med. 2016;29(5):696-700. Razón de exclusión: incluye pacientes con dilatación mayor a $4 \mathrm{~cm}$.

8. MetroHealth Medical Center. NCT01869361. Disponible en https://clinicaltrials.gov/ct2/show/ NCT01869361. Razón de exclusión: sin resultados.

9. Niebyl JR, Blake DA, White RD, Kumor KM, Dubin NH, Robinson JC, et al. The inhibition of premature labor with indomethacin. Am J Obstet Gynecol. 1980;136(8):1014-9. Razón de exclusión: incluye pacientes con edad gestacional fuera del rango de interés.

10. Nisell H, Wolff K. Effectiveness and safety of the oxytocin antagonist atosiban versus beta-adrenergic agonists in the treatment of preterm labour. BJOG. 2003;110(1):89. Razón de exclusión: no hacen un análisis diferenciado del atosiban vs. cada uno de los beta-agonistas.

11. Hospital Clínico Universitario de Santiago. NCT01314859. 2014 (visiado 2017 jun 21). Disponible en: https://clinicaltrials.gov/ct2/show/ NCT01314859. Razón de exclusión: Este estudio ha sido retirado antes de la inscripción.

12. Padovani TR, Lopes LC. Nifedipine and terbutaline: Comparative study of effectiveness and safety in preventing preterm labor. Int J Gynecol Obstet. 2012;119:S761. Razón de exclusión: poster.

13. Parry E, Roos C, Stone P, Hayward L, Mol BW, McCowan L. The NIFTY study: A multi-centre randomised double blind placebo controlled trial of nifedipine maintenance tocolysis in Fetal Fibronectin positive women in threatened preterm labour. Am J Obstet Gynecol. 2012;206(1):S216. Razón de exclusión: no incluye población de interés.

14. Saint Thomas Hospital. NCT01360034. 2015 (visitado 2017 jul 1). Disponible en: https://clinicaltrials. gov/ct2/show/NCT01360034. Razón de exclusión: sin resultados. 
15. Stanford University. NCT00486824. 2015 (visitado 2017 jul 1). Disponible en: https://clinicaltrials.gov/ ct2/show/NCT00486824?term = NCT00486824\&re crs $=$ a\&rank $=1$. Razón de exclusión: sin resultados.

16. Thomas Jefferson University. NCT00466128. 2015 (visitado 2017 jul 1). Disponible en: https://clinicaltrials.gov/ct2/show/NCT00466128. Razón de exclusión: sin resultados.
17. Valenzuela GJ, Sanchez-Ramos L, Romero R, Silver HM, Koltun WD, Millar L, et al. Maintenance treatment of preterm labor with the oxytocin antagonist atosiban. Am J Obstet Gynecol. 2000;182(5):118490. Razón de exclusión: No cumple con los criterios de la población estudiada. Incluye pacientes desde la semana 20 hasta la semana 36. 
Annex 4.

Evidence summary tables and GRADE qualification for NMA

\section{Effect estimators, confidence intervals and certainty in evidence for the use of atosiban in treatment of adult pregnant patients with threatened preterm delivery.}

SOF- NMA

Type of population: adult pregnant patients with threatened preterm delivery

Interventions: atosiban

Comparison (reference): fenoterol, nifedipine, terbutaline

Environment: patient

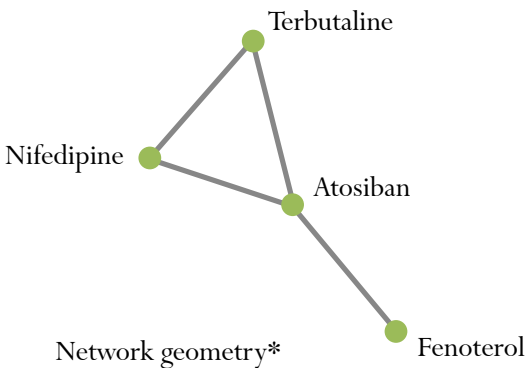

\begin{tabular}{|c|c|c|c|c|c|c|}
\hline \multirow{2}{*}{$\begin{array}{l}\text { Total studies: } \\
8 \text { studies } \\
\text { Total partici- } \\
\text { pants: } 1436 \\
\text { patients }\end{array}$} & \multirow{2}{*}{$\begin{array}{c}\text { Relative } \\
\text { effect }^{* *}(95 \% \\
\text { CrL })\end{array}$} & \multicolumn{3}{|c|}{ Absolute anticipated effects ${ }^{* * *}(95 \% \mathrm{CrL})$} & \multirow[b]{2}{*}{$\begin{array}{c}\text { Certainty of } \\
\text { evidence }\end{array}$} & \multirow[b]{2}{*}{ Ranking } \\
\hline & & $\begin{array}{l}\text { Without } \\
\text { intervention }\end{array}$ & $\begin{array}{l}\text { With } \\
\text { intervention }\end{array}$ & Difference & & \\
\hline Atosiban & - & - & $680 / 1000$ & - & - & $\begin{array}{l}P=1 \\
0.8059\end{array}$ \\
\hline $\begin{array}{c}v s . \\
\text { Fenoterol }\end{array}$ & $\begin{array}{c}1.26 \text { (1 a } 1.59) \\
\text { Network estimate }\end{array}$ & $540 / 1000$ & $680 / 1000$ & $\begin{array}{l}140 \text { more per } 1000 \\
\text { (from } 0 \text { plus to } 252 \text { plus) }\end{array}$ & $\begin{array}{c}\bigoplus \bigoplus \oplus \mathrm{O}^{1,2,3,5} \\
\text { Moderate }\end{array}$ & $\begin{array}{c}P=4 \\
0.0620\end{array}$ \\
\hline $\begin{array}{c}v s . \\
\text { Nifedipine }\end{array}$ & $\begin{array}{c}1,02 \\
(0,91 \text { a } 1,15) \\
\text { Network estimate }\end{array}$ & $667 / 1000$ & $680 / 1000$ & $\begin{array}{c}13 \text { more per } 1000 \\
\text { (from } 67 \text { minus to } \\
89 \text { plus) }\end{array}$ & $\begin{array}{l}\oplus \oplus \bigoplus \mathrm{O}^{1,2,4,5} \\
\text { Moderate }\end{array}$ & $\begin{array}{c}P=2 \\
0.6649\end{array}$ \\
\hline $\begin{array}{c}\text { vs. } \\
\text { Terbutaline }\end{array}$ & $\begin{array}{c}1.06 \\
(0.93 \text { a } 1.21) \\
\text { Network estimat }\end{array}$ & $641 / 1000$ & $680 / 1000$ & $\begin{array}{c}38 \text { more per } 1000 \\
\text { (from } 51 \text { minus to } 118 \\
\text { plus) }\end{array}$ & $\begin{array}{l}\oplus \oplus \bigoplus \mathrm{O}^{1,2,4} \\
\text { Moderate }\end{array}$ & $\begin{array}{l}P=3 \\
0.4672\end{array}$ \\
\hline
\end{tabular}

\section{Definition table of MAR-TRH}

* Lines represent direct comparisons

${ }^{* *}$ Estimators of the meta-analysis with confidence interval. Bayes method.

${ }^{* * * *}$ Absolute anticipated effects calculated for the trials Van Vliet EOG, Nijman TAJ, Schuit E, Heida KY, Opmeer BC, Kok M, et al. Nifedipine vs. atosiban for threatened preterm birth (APOSTEL III): A multicentre, randomized controlled trial. Lancet. 2016; 21; 387(10033):

2117-24. doi: 10.1016/S0140-6736(16)00548-1.

***** Statistic ranking: P score. Probability values of likelihood of being the best therapeutic course.

\section{Certainty of evidence (GRADE system)}

High quality: high confidence that the real effect is found near the estimated effect.

Moderate quality: moderate confidence in the estimated effect: there is a possibility that the real effect is found near the estimated effect, however, they possibly differ in a substantial way.

Low quality: the confidence of the estimated effect is limited: the real effect may be substantially different to the estimated.

Very low quality: there is very little confidence in the estimated effect: the real effect is likely very different from the estimated effect.

\section{Explanations}

1. This effect was determined by a random factor of the model due to heterogeneity $(\mathrm{I} 2=44,7)$.

2. Coherence: consistency between the effects of interventions from direct and indirect comparisons.

3. Indirect evidence: indirect evidence for this comparison is found in a first degree connection.

4. Indirect evidence: indirect evidence for this comparison is found in a second degree connection, even though most of the estimation comesfrom direct evidence.

5. Imprecision: the 95\% CI considers there is no effect/clinically relevant effect. 


\section{Effect estimators, confidence intervals and certainty in evidence for the use of atosiban in treatment} of adult pregnant patients with threatened preterm delivery.

SOF- NMA

Type of population: Adult pregnant patients with threatened preterm delivery.

Interventions: atosiban

Comparison: fenoterol, nifedipine, terbutaline.

Environment: patient

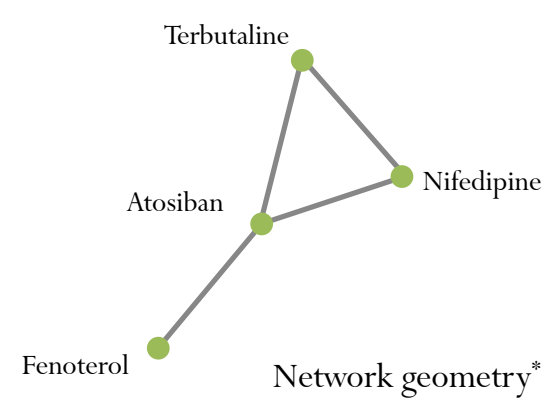

\begin{tabular}{|c|c|c|c|c|c|c|}
\hline \multicolumn{7}{|c|}{ Outcome: time delay for delivery $>7$ days } \\
\hline \multirow{2}{*}{$\begin{array}{l}\text { Total studies: } \\
7 \text { studies } \\
\text { Total participants: } \\
1305 \text { patients }\end{array}$} & \multirow{2}{*}{$\begin{array}{l}\text { Relative effect } \\
\text { (95\% CrL) }\end{array}$} & \multicolumn{3}{|c|}{$\begin{array}{l}\text { Absolute anticipated effects } \\
\text { (95\% CrL) }\end{array}$} & \multirow{2}{*}{$\begin{array}{l}\text { Certainty of } \\
\text { evidence }\end{array}$} & \multirow{2}{*}{ Ranking ${ }^{* * * *}$} \\
\hline & & $\begin{array}{l}\text { Without } \\
\text { intervention }\end{array}$ & $\begin{array}{l}\text { With } \\
\text { intervention }\end{array}$ & Difference & & \\
\hline Atosiban & - & - & $510 / 1000$ & - & - & $\begin{array}{c}\mathrm{P}=1 \\
0.79\end{array}$ \\
\hline $\begin{array}{c}\text { vs. } \\
\text { Fenoterol }\end{array}$ & $\begin{array}{c}1,18 \\
(0.71 \text { a } 1.95) \\
\text { Network estimate }\end{array}$ & $432 / 1000$ & $510 / 1000$ & $\begin{array}{c}78 \text { more } \\
\text { per } 1000 \\
\text { (from } 208 \\
\text { minus to } 248 \\
\text { plus) }\end{array}$ & $\begin{array}{c}\bigoplus \bigoplus \bigoplus \mathrm{O} 1,2,4 \\
\text { Moderate }\end{array}$ & $\begin{array}{c}P=3 \\
0.43\end{array}$ \\
\hline $\begin{array}{c}v s . \\
\text { Nifedipine }\end{array}$ & $\begin{array}{c}1,06 \\
(0.82 \text { a } 1.37) \\
\text { Network estimate }\end{array}$ & $481 / 1000$ & $510 / 1000$ & $\begin{array}{c}29 \text { more } \\
\text { per } 1000 \\
\text { (from } 112 \\
\text { minus to } 138 \\
\text { plus) }\end{array}$ & $\begin{array}{l}\oplus \oplus \oplus \mathrm{O} 1,2,5 \\
\text { Moderate }\end{array}$ & $\begin{array}{c}P=2 \\
0.63\end{array}$ \\
\hline $\begin{array}{c}\text { vs. } \\
\text { Terbutaline }\end{array}$ & $\begin{array}{c}1.37 \\
(0.99 \text { a } 1.89) \\
\text { Network estimate }\end{array}$ & $372,3 / 1000$ & $510 / 1000$ & $\begin{array}{l}138 \text { more } \\
\text { per } 1000 \\
\text { (from } 5 \text { minus } \\
\text { to } 240 \text { plus) }\end{array}$ & $\begin{array}{c}\bigoplus \oplus \text { OO } 1,2,5 \\
\text { Low }\end{array}$ & $\begin{array}{c}\mathrm{P}=4 \\
0.13\end{array}$ \\
\hline
\end{tabular}

\section{Definition table of MAR-TRH}

* Lines represent direct comparisons

** Estimators of the meta-analysis with confidence interval. Bayesian method.

*** Absolute anticipated effects calculated for the trials Van Vliet EOG, Nijman TAJ, Schuit E, Heida KY, Opmeer BC, Kok M, et al. Nifedipine vs. atosiban for threatened preterm birth (APOSTEL III): A multicentre, randomized controlled trial. Lancet. 2016; 21; 387(10033):

2117-24. doi: 10.1016/S0140-6736(16)00548-1.

**** Statistic ranking: P score. Probability values of likelihood of being the best therapeutic course..

\section{Certainty of evidence (GRADE system)}

High quality: high confidence that the real effect is found near the estimated effect.

Moderate quality: moderate confidence in the estimated effect: there is a possibility that the real effect is found near the estimated effect, however, they possibly differ in a substantial way.

Low quality: the confidence of the estimated effect is limited: the real effect may be substantially different to the estimated.

Very low quality: there is very little confidence in the estimated effect: the real effect is likely very different from the estimated effect.

\section{Explanations}

1. This effect was determined by a random factor of the model due to heterogeneity $(\mathrm{I} 2=82,2)$.

2. Coherence: consistency between the effects of interventions from direct and indirect comparisons.

3. Indirect evidence: indirect evidence for this comparison is found in a first degree connection.

4. Indirect evidence: indirect evidence for this comparison is found in a second degree connection, even though most of the estimation comes from direct evidence.

5. Imprecision: the 95\% CI considers there is no effect/clinically relevant effect. 
Effect estimators, confidence intervals and certainty in evidence for the use of atosiban in treatment of adult pregnant patients with risk of preterm delivery.

SOF- NMA

Type of population: adult pregnant patients with threatened preterm delivery.

Intervenciones: atosiban

Comparison (reference): fenoterol, nifedipine, terbutaline

\section{Indomethacin}

Nifedipine

Comparison (reference): fenoterol, nifedipine, terbutaline

\begin{tabular}{|c|c|c|c|c|c|c|}
\hline \multicolumn{5}{|l|}{ Environment: patient } & \multicolumn{2}{|c|}{ Network geometry ${ }^{*}$} \\
\hline \multicolumn{7}{|c|}{ Outcome : Neonatal mortality } \\
\hline \multirow{2}{*}{$\begin{array}{l}\text { Total studies: } \\
3 \text { studies } \\
\text { Total participants: } \\
835 \text { patients }\end{array}$} & \multirow{2}{*}{$\begin{array}{c}\text { Relative } \\
\text { effect }^{* *} \\
(95 \% \text { CrL) }\end{array}$} & \multicolumn{3}{|c|}{ Absolute anticipated effects ${ }^{* * *}(95 \%$ CrL) } & \multirow{2}{*}{$\begin{array}{l}\text { Certainty of } \\
\text { evidence }\end{array}$} & \multirow[b]{2}{*}{ Ranking ${ }^{* * * *}$} \\
\hline & & $\begin{array}{c}\text { Without } \\
\text { intervention }\end{array}$ & $\begin{array}{c}\text { With } \\
\text { intervention }\end{array}$ & Difference & & \\
\hline Atosiban & - & - & $50 / 1000$ & - & - & $\begin{array}{l}P=1 \\
0.9284\end{array}$ \\
\hline $\begin{array}{c}\text { vs. } \\
\text { Indomethacin }\end{array}$ & $\begin{array}{c}0.21 \\
(0.05 \text { a } 0.92) \\
\text { Network } \\
\text { estimate }\end{array}$ & $238 / 1000$ & $50 / 1000$ & $\begin{array}{l}188 \text { less per } 1000 \\
\text { (from } 4 \text { minus to } \\
950 \text { minus) }\end{array}$ & $\begin{array}{c}\bigoplus \bigoplus \text { OO } 1,3,4 \\
\text { Low }\end{array}$ & $\begin{array}{l}P=4 \\
0.1038\end{array}$ \\
\hline $\begin{array}{c}\text { vs. } \\
\text { Nifedipine }\end{array}$ & $\begin{array}{c}0.45 \\
(0.19 \text { a } 1.1) \\
\text { Network } \\
\text { estimate }\end{array}$ & $111 / 1000$ & $50 / 1000$ & $\begin{array}{l}61 \text { menos por } 1000 \\
\text { (de } 213 \text { menos a } \\
5 \text { más) }\end{array}$ & $\begin{array}{c}\oplus \oplus \text { OO } 1,2,5 \\
\text { Low }\end{array}$ & $\begin{array}{l}P=3 \\
0.4651\end{array}$ \\
\hline $\begin{array}{c}\text { vs. } \\
\text { Terbutaline }\end{array}$ & $\begin{array}{c}0.5 \\
(0.13 \text { a } 1.91) \\
\text { Network } \\
\text { estimate }\end{array}$ & $100 / 1000$ & $50 / 1000$ & $\begin{array}{l}50 \text { less per } 1000 \\
\text { (from } 335 \text { minus } \\
\text { to } 24 \text { plus) }\end{array}$ & $\begin{array}{c}\oplus \oplus \mathrm{OO}, 1,2,5 \\
\text { Low }\end{array}$ & $\begin{array}{l}P=2 \\
0.5027\end{array}$ \\
\hline
\end{tabular}

Definition table of MAR-TRH

${ }^{*}$ Lines represent direct comparisons

** Estimators of the meta-analysis with confidence interval. Bayesian method.

**** Absolute anticipated effects calculated for the trials Van Vliet EOG, Nijman TAJ, Schuit E, Heida KY, Opmeer BC, Kok M, et al. Nifedipine vs. atosiban for threatened preterm birth (APOSTEL III): A multicentre, randomized controlled trial. Lancet. 2016; 21; 387(10033): 2117-24. doi: 10.1016/S0140-6736(16)00548-1.

***** Statistic ranking: P score. Probability values of likelihood of being the best therapeutic course.

Certainty of evidence (GRADE system)

High quality: high confidence that the real effect is found near the estimated effect.

Moderate quality: moderate confidence in the estimated effect: there is a possibility that the real effect is found near the estimated effect, however, they possibly differ in a substantial way.

Low quality: the confidence of the estimated effect is limited: the real effect may be substantially different to the estimated.

Very low quality: there is very little confidence in the estimated effect: the real effect is likely very different from the estimated effect.

Explanations

1. Heterogeneity is null $(\mathrm{I} 2=0)$.

2. Coherence: consistency between the effects of interventions from direct and indirect comparisons.

3. Indirect evidence: indirect evidence for this comparison is found in a first degree connection.

4. Indirect evidence: indirect evidence for this comparison is found in a second degree connection, even though most of the estimation comes from direct evidence. 
Effect estimators, confidence intervals and certainty in evidence for the use of atosiban for the treatment of adult pregnant patients with threatened preterm delivery

SOF- NMA

Type of population: adult pregnant patients with threatened preterm delivery.

Terbutaline

Intervenciones: atosiban

Comparison (reference): fenoterol, nifedipine, terbutaline

Outcome: maternal adverse events

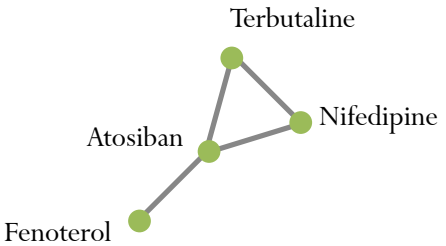

Environment: patient

Network geometry"

\begin{tabular}{|c|c|c|c|c|c|c|}
\hline \multicolumn{7}{|c|}{ Maternal adverse events } \\
\hline \multirow{2}{*}{$\begin{array}{l}\text { Total studies: } \\
5 \text { studies } \\
\text { Total participants: } \\
588 \text { patients }\end{array}$} & \multirow{2}{*}{$\begin{array}{l}\text { Relative } \\
\text { effect }{ }^{* *} \\
(95 \% \mathrm{CrL})\end{array}$} & \multicolumn{3}{|c|}{ Absolute anticipated effects ${ }^{* * * * *}(95 \% \mathrm{CrL})$} & \multirow{2}{*}{$\begin{array}{l}\text { Certainty of } \\
\text { evidence }\end{array}$} & \multirow{2}{*}{ Ranking $^{* * * *}$} \\
\hline & & $\begin{array}{l}\text { Without } \\
\text { intervention }\end{array}$ & Difference & Difference & & \\
\hline Atosiban & - & - & $60 / 1000$ & - & - & $\begin{array}{c}P=1 \\
0.99\end{array}$ \\
\hline $\begin{array}{c}\text { vs. } \\
\text { Fenoterol }\end{array}$ & $\begin{array}{c}0.16 \\
(0.08 \text { to } 0,31) \\
\text { Network } \\
\text { estimate }\end{array}$ & $375 / 1000$ & $60 / 1000$ & $\begin{array}{c}315 \text { less per } 1000 \\
\text { (from } 134 \text { minus to } \\
690 \text { plus) }\end{array}$ & $\begin{array}{c}\oplus \bigoplus \bigoplus \mathrm{O} 1,2,4 \\
\text { Moderate }\end{array}$ & $\begin{array}{l}P=4 \\
0.004\end{array}$ \\
\hline $\begin{array}{c}\text { vs. } \\
\text { Nifedipine }\end{array}$ & $\begin{array}{c}0.48 \\
(0.3 \text { a } 0.78) \\
\text { Network } \\
\text { estimate }\end{array}$ & $125 / 1000$ & $60 / 1000$ & $\begin{array}{c}65 \text { less per } 1000 \\
\text { (from } 17 \text { minus to } 140 \\
\text { minus) }\end{array}$ & $\begin{array}{c}\oplus \bigoplus \bigoplus \mathrm{O} 1,2,4 \\
\text { Moderate }\end{array}$ & $\begin{array}{c}P=2 \\
0.55\end{array}$ \\
\hline $\begin{array}{c}\text { vs. } \\
\text { Terbutaline }\end{array}$ & $\begin{array}{c}0.44 \\
(0,28 \text { a } 0,71) \\
\text { Network } \\
\text { estimate }\end{array}$ & $136 / 1000$ & $60 / 1000$ & $\begin{array}{c}76 \text { less per } 1000 \\
\text { (from } 25 \text { minus to } 154 \\
\text { minus) }\end{array}$ & $\begin{array}{c}\oplus \bigoplus \bigoplus \mathrm{O} 1,2,3 \\
\text { Moderate }\end{array}$ & $\begin{array}{c}P=3 \\
0.45\end{array}$ \\
\hline
\end{tabular}

\section{Definition table of MAR-TRH}

${ }^{*}$ Lines represent direct comparisons

** Estimators of the meta-analysis with confidence interval. Bayesian method.

*** Absolute anticipated effects calculated for the trials Van Vliet EOG, Nijman TAJ, Schuit E, Heida KY, Opmeer BC, Kok M, et al. Nifedipine vs. atosiban for threatened preterm birth (APOSTEL III): A multicentre, randomized controlled trial. Lancet. 2016; 21; 387(10033): 2117-24. doi: 10.1016/S0140-6736(16)00548-1.

**** Statistic ranking: P score. Probability values of likelihood of being the best therapeutic course.

\section{Certainty of evidence (GRADE system)}

High quality: high confidence that the real effect is found near the estimated effect.

Moderate quality: moderate confidence in the estimated effect: there is a possibility that the real effect is found near the estimated effect, however, they possibly differ in a substantial way.

Low quality: the confidence of the estimated effect is limited: the real effect may be substantially different to the estimated.

Very low quality: there is very little confidence in the estimated effect: the real effect is likely very different from the estimated effect.

Explicaciones

1. Heterogeneity is null $(\mathrm{I} 2=0)$.

2. Direct evidence: evidence is based completely in direct evidence.

3. Indirect evidence: the model estimation considers a first degree indirect comparison, but most of the data comes from direct comparison.

4. Risk of bias: for this outcome, it is considered important for open studies as input in this comparison. 